\title{
20. PLIOCENE AND PLEISTOCENE ABUNDANCE AND PRESERVATION OF SILICEOUS MICRO- FOSSIL ASSEMBLAGES FROM SITES 794, 795, AND 797: IMPLICATIONS FOR CIRCULATION AND PRODUCTIVITY IN THE JAPAN SEA ${ }^{1}$
}

\author{
Lisa D. White ${ }^{2}$ and Joanne M. Alexandrovich ${ }^{3}$
}

\begin{abstract}
A close examination of the siliceous microfossil assemblages from the sediments of ODP Leg 127, Japan Sea Sites 794, 795, and 797, reveals that upper Pliocene and Pleistocene assemblages have been subjected to more dissolution than have lower Pliocene assemblages. This conclusion is based on semiquantitative observations of samples processed for diatoms and radiolarians. Although preservation of opaline microfossils in some upper Pliocene and Pleistocene samples is better than others, in general, the poorly preserved state of these assemblages supports the notion that opal dissolution, in response to lowered productivity, is responsible for the paucity of siliceous microfossils in upper Pliocene and Pleistocene sediments. The lithological transition from diatomaceous oozes to silts and clays corresponds to a change between dominantly well preserved to more poorly preserved siliceous assemblages, and is termed the late Pliocene Japan Sea opal dissolution transition zone (ODTZ). The base of the ODTZ is defined as the uppermost occurrence of high abundances of moderately to well preserved valves of the diatom Coscinodiscus marginatus. The dissolution transition zone is characterized by partially dissolved refractory assemblages of radiolarians, the presence of $C$. marginatus girdles, $C$. marginatus fragments, siliceous sponge spicules, and a general decrease in weakly silicified, less solution resistant diatoms upward in the section. The top of the dissolution transition zone marks the level where whole $C$. marginatus valves and $C$. marginatus fragments are no longer present in significant numbers.

Dissolution of the late Pliocene and Pleistocene opaline assemblages is attributed mainly to changes in paleoceanographic circulation patterns and decreased nutrient (dissolved silicon) contents of the water column, and possibly dissolution at the sediment/water interface, rather than to post-depositional dissolution or diagenesis. We suggest that the transition from silica-rich to silica-poor conditions in the Japan Sea was due to fluctuations of deep-water exchange with the Pacific through the Tsugaru Strait between 2.9 and $2.3 \mathrm{Ma}$.
\end{abstract}

\section{INTRODUCTION}

A primary purpose of Leg 127 was to determine the paleoceanographic evolution of the Japan Sea by examining the record of microfossil assemblages, in particular siliceous microfossils. A conspicuous feature of Japan Sea sediments is the diagenetic transformation of opal-A to opal-CT between 200 and $300 \mathrm{mbsf}$, caused by optimal conditions of sediment thickness, age, and heat flow (Langseth and Tamaki, this volume). Unfortunately, the relatively shallow occurrence of the opalA/CT transition has obliterated most of the paleontological record of siliceous sedimentation below the opal-A/CT boundary, limiting the age of preserved opaline microfossils in the sediments cored during Leg 127 to no older than late Miocene or $\sim 8 \mathrm{Ma}$.

In general, above the opal-A/opal-CT diagenetic boundary the upper Miocene and lower Pliocene sediments of all four sites (Fig. 1) sampled in the Japan Sea during Leg 127 are rich in siliceous microfossil remains (diatom silty clays and oozes). The siliceous microfossils found in these sediments (diatoms, radiolarians, and siliceous sponge spicules) are moderately to well preserved and are typically common to abundant. In contrast, upper Pliocene and Pleistocene sediments of the sites contain low percentages of diatoms and are composed mainly of silts, clays, and ashes. Furthermore, uppermost Pleistocene sediments display distinctive alternating light and dark layers, with siliceous microfossils showing variable states of abundance and preservation.

\footnotetext{
' Pisciotto, K. A., Ingle, J. C., Jr., von Breymann, M. T., Barron, J., et al., 1992. Proc. ODP, Sci. Results, 127/128, Pt. 1: College Station, TX (Ocean Drilling Program).

${ }^{2}$ Department of Geosciences, San Francisco State University, San Francisco, CA 94132 , U.S.A.

${ }^{3}$ Department of Geological Sciences, Columbia University and Lamont-Doherty Geological Observatory, Palisades, NY 10964, U.S.A. (Current address: Department of Geology, Florida Atlantic University, Boca Raton, FL 33431, U.S.A.)
}

\section{PURPOSE OF STUDY}

Because of the stark contrast between relatively silica-poor upper Pliocene and Pleistocene sediments and silica-rich lower Pliocene and upper Miocene sediments, and the assumption that high siliceous plankton productivity in the water column is accompanied by high opal contents in the underlying sediments (Leinen et al., 1986), the Shipboard Scientific Party (1990b-e), and Tamaki, Pisciotto, Allan, et al. (1990) concluded that the Miocene and early Pliocene waters of the Japan Sea were very productive. Preliminary surveys of samples from the diatomaceous oozes revealed large abundances of the diatom Coscinodiscus marginatus. The presence of this diatom complicated assemblage descriptions because it is not present in such high proportions in plankton samples in the North Pacific (Sancetta, 1982), suggesting it is a dissolution-resistant form (Burckle, Sturz, and Emanuele, this volume). Our approach in this paper is to describe and interpret the differences in the siliceous microfossil assemblages over the interval between the diatom-rich oozes and the diatom-poor clays and silts in order to determine the nature of Pliocene and Pleistocene paleoceanographic change in the Japan Sea.

\section{The Record of Coscinodiscus marginatus}

Coscinodiscus marginatus is a conspicuous component of the sediments of Japan Sea Sites 794, 795, and 797. This diatom is abundant ( $\sim 50 \%$ of the diatom assemblages) in the clayey diatomaceous oozes. Because it is quite large $(30-100 \mu \mathrm{m}$ in diameter), it comprises a large proportion of the $>63 \mu \mathrm{m}$ size fraction. Coscinodiscus marginatus is both a paleoenvironmental indicator and a dissolution indicator (Schrader, 1973) as well as an important component in North Pacific assemblages (Sancetta and Silvestri, 1986). Coscinodiscus marginatus is considered to be transitional between subtropical and subarctic water masses (Sancetta and Silvestri, 1986). Sancetta and Silvestri (1986) note its abundance in a piston core of calcareous-siliceous ooze from the northeastern Pacific (Core V20-119) between 


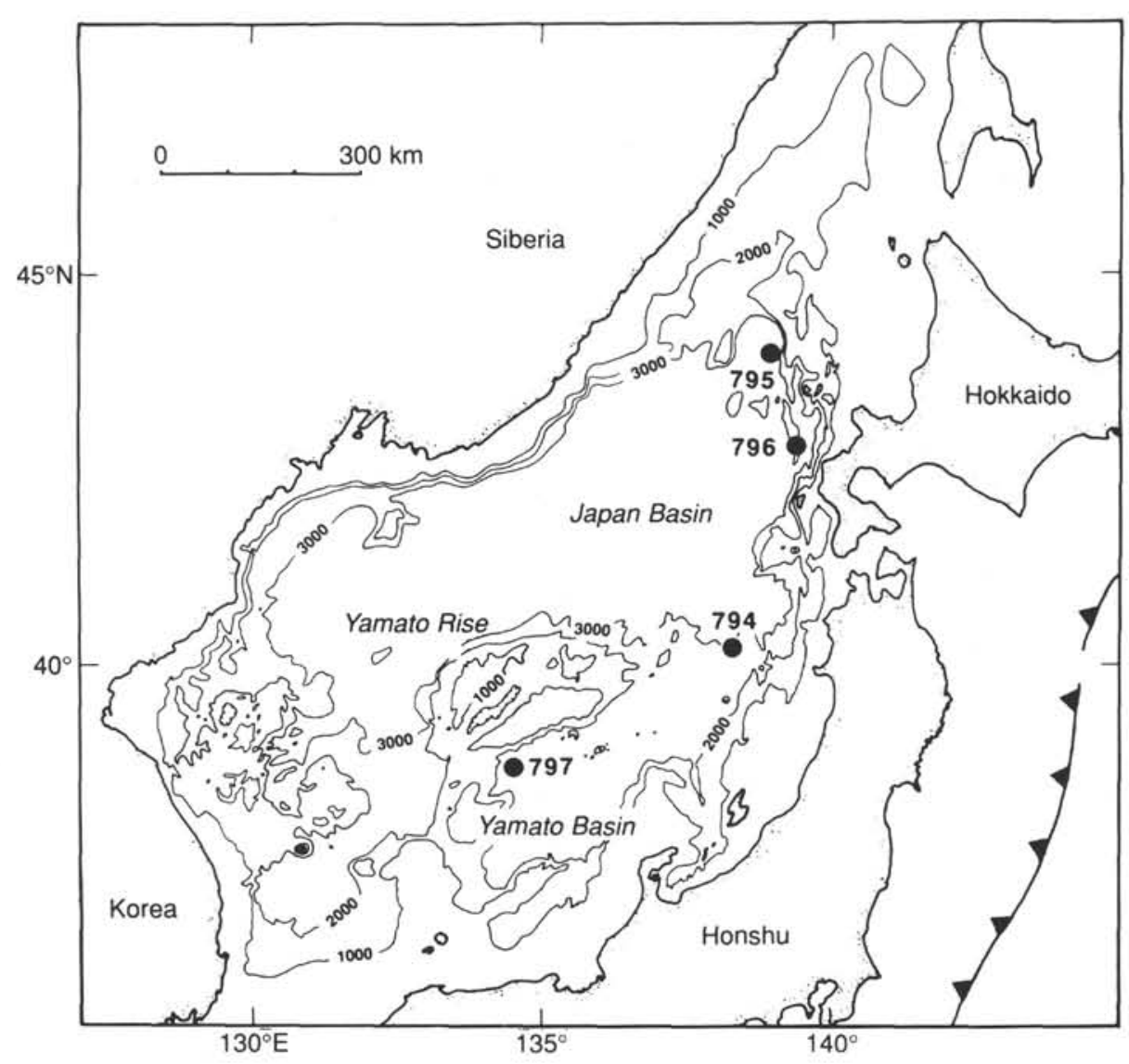

Figure 1. Map of the Japan Sea showing the location of ODP Leg 127 Sites 794-797.

$\sim 2.6$ and $2.4 \mathrm{Ma}$ and suggest it was deposited during times of high productivity in the surface waters. Furthermore, Sancetta and Silvestri (1986) note the decline of C. marginatus after $2.4 \mathrm{Ma}$ to minimum values at $\sim 2.0 \mathrm{Ma}$. The investigators conclude that strong yet fluctuating degrees of stratification of North Pacific surface water masses occurred at this time as a result of glacial-interglacial cycles. Our observations suggest that the overall abundance and preservation of diatoms and radiolarians decreases following peak abundances of $C$. marginatus, and generally corresponds to the lithologic break between diatom oozes and diatom clays. Furthermore, the presence of dissolution-resistant radiolarians such as Trissocyclids (similar to what was observed by Holdsworth and Harker, 1975) in the Pleistocene diatom clays with variably abundant and fragmented $C$. marginatus frustules, is in agreement with increased dissolution at this time.

\section{Opal Dissolution Transition Zone (ODTZ)}

The opal dissolution transition zone (ODTZ) is an interval we recognize in the Japan Sea cores that marks the change between dominantly well preserved to more poorly preserved siliceous assemblages. It generally corresponds to a lithological change between diatomaceous oozes and diatom silts and clays. We define the base of the ODTZ as the uppermost occurrence of high abundances of whole C. marginatus valves or "Coscinodiscus oozes" (Burckle, this volume). Within the ODTZ the following components are common: partially dissolved and broken $C$. marginatus valves and girdles; siliceous sponge spicules; and partially dissolved radiolarians. The top of the ODTZ is marked by the decrease in the numbers of whole C. marginatus and C. marginatus fragments. We discuss the nature of the ODTZ at each site and its paleoceanographic significance in the results and discussion sections.

\section{OCEANOGRAPHIC SETTING}

The Japan Sea is a relatively young back-arc basin that began opening in the late Oligocene or early Miocene (Leg 127 and Leg 128 Shipboard Scientific Parties, 1990). Since this time, complex tectonic activity has resulted in changes in the shape and boundaries of the basins of the Japan Sea (Iijima and Tada, 1990), which have undoubtedly affected the paleoceanography and depositional conditions of this marginal sea. The Japan Sea is divided into two deep basins: the Japan Basin to the north (maximum water depth $\sim 3700 \mathrm{~m}$, Tamaki, 1988); and the Yamato Basin to the south (Fig. 1, maximum water depth $\sim 3000 \mathrm{~m}$, Tamaki, 1988). The waters in these basins are topographically isolated from Pacific intermediate and deep water masses at the sills of shallow straits. The straits include (from south to north) the Tsushima Strait between Honshu and Korea at a depth of $130 \mathrm{~m}$, the Tsugaru Strait between Honshu and Hokkaido at $130 \mathrm{~m}$, the Soya Strait between Hokkaido and Sakhalin at $55 \mathrm{~m}$, and the Tatar Strait between Sakhalin and Asia at $12 \mathrm{~m}$ (Ingle, 1975).

The present day oceanographic and climatic conditions of the Japan Sea keep the waters of the Japan Sea well mixed and well oxygenated (hyperventilated). In the northern region, cold waters with high oxygen content flow south in the Liman Current, sink rapidly, and serve to fill, $\mathrm{mix}$, and ventilate the highly productive basin. Surface waters enter the Japan Sea through the Tsushima Strait as the Tsushima Current (an arm of the warm Kuroshio), and flow out from the Tsugaru Strait (Ingle, 1975; Matoba 1984). Assuming the straits were in approximately the same tectonic positions during glacial times when sea level was lower, the depths of the sills of these straits were shallower and flow was reduced or completely restricted. Studies of latest Pleistocene and Holocene Japan Sea sediments suggest that during certain periods, the deep basins have been stagnant, flow has been cut off at the Tsushima Strait, and water of 
the Oyashio Current flowed into the basin (see Kobayashi, 1985; Koizumi, 1989; Oba et al., 1991). Such changes in circulation are closely tied to Pleistocene Northern Hemisphere glaciations and may have caused reversals between oxic, anoxic, or suboxic states, and have undoubtedly affected the depositional conditions and sedimentary deposits in the basins of the Japan Sea (Tada and Iijima, this volume).

Four sites were cored in the Japan Sea during Ocean Drilling Program Leg 127. Sites 794, 795, and 796 are located in approximate water depths of 2810,3300 , and $2600 \mathrm{~m}$, respectively, along the eastern margin of the Japan Basin, and Site 797, at a water depth of $2860 \mathrm{~m}$ is located in the southwestern part of the Yamato Basin near the Yamato Rise (Tamaki, Pisciotto, Allan, et al., 1990). Today, Sites 797 and 794 are both located beneath the path of the Tsushima current, while Sites 796 and 795, are influenced by the colder more northern waters of the Liman and North Korean Current. Thick sedimentary sections ( $500 \mathrm{~m}$ thick) were cored at each of these sites with recoveries in unlithified sediments averaging $\sim 75 \%$. Biostratigraphic data suggest the sediments recovered at each site provide a continuous record of Pliocene and Pleistocene biogenic sedimentation.

\section{METHODS}

One sample/section was obtained from Holes 794A, 795A, and 797B, down to the opal-A/opal-CT transition, for diatom and radiolarian analysis. Site 796 was not sampled because it is located in an active tectonic zone. The frequent coarse clastic deposits and slumped units which comprise the record at this site make environmental interpretations of the microfossil assemblages suspect (Shipboard Scientific Party, 1990d). The data presented here are restricted to Pliocene and Pleistocene cores where the transition from silica-rich to silica-poor sediments can best be observed.

\section{Diatoms}

For this study, samples processed for diatoms were disaggregated in water and a solution of $10 \% \mathrm{H}_{2} \mathrm{O}_{2}$ over low heat for $\sim 10-30 \mathrm{~min}$. The solution was then removed from the heat source and allowed to settle. After sufficient cooling, the liquid was decanted and additional water was added to resuspend the residue. Material was then pipetted from the top $1 \mathrm{~mL}$ of suspended residue and strewn onto a cover slip. This randomly settled material was then mounted to a glass slide with Hyrax.

Two slides/sample were made and examined at a magnification of $500 \times$ by traversing the long dimension of the slide $(30 \mathrm{~mm})$ between 5 and 10 times, depending on the abundance of diatoms in the sample. Positive identification of diatom species was confirmed at a magnification of $1250 \times$. Relative abundances of diatoms reflect percentage estimates of diatom valves relative to other sedimentary material on the slide (Shipboard Scientific Party, 1990a). Similarly, species abundances reflect percentage estimates of the species listed in Tables 1-3 relative to other diatoms in the assemblage. The following convention was used: $\mathrm{A}=\mathrm{Abundant},>50 \% ; \mathrm{C}=\mathrm{Common}, 25 \%-50 \% ; \mathrm{F}=\mathrm{Few}$, $1 \%-25 \% ; \mathrm{R}=$ Rare, $<1 \% ; \mathrm{B}=$ Barren, no diatoms present.

Preservation of diatoms is based on the presence of complete or broken thinly silicified or heavily silicified valves (Shipboard Scientific Party, 1990a). The following three categories were classified:

$\mathrm{G}=$ Good: well preserved with numerous delicate diatom frustules

$\mathrm{M}=$ Moderate: mostly heavily silicified frustules with some thinly silicified valves present

$\mathrm{P}=$ Poor: only heavily silicified valves present.

Listed in Tables 1-3 are the abundances of diatoms that are generally diagnostic of Pliocene and Quaternary assemblages of the North Pacific (Koizumi, 1986; Sancetta and Silvestri, 1986). The abundance of Coscinodiscus marginatus and $C$. marginatus girdles are listed next to abundance and preservation data on the tables to emphasize how closely fluctuations in the abundance of $C$. marginatus reflect the overall abundance and preservation of the diatom assemblages. Also shown in the tables is the abundance of siliceous sponge spicules in these slides, which may be a function of increased transport of sediments and/or preservation.

\section{Radiolarians}

The collection of quantitative data from the radiolarian assemblages contained in Leg 127 Japan Sea sediments is complicated by large apparent variations in preservation, uncataloged diversity, and taxonomic uncertainties. Therefore, estimates of productivity from these assemblages are tentative, at best. For this study, samples processed for radiolarian paleontology (one sample/section, the $>63 \mu \mathrm{m}$ size fraction of organic and carbonate-free material), were scanned with a light microscope, and estimates of radiolarian preservation and abundance were made on the late Pliocene and Pleistocene intervals (Alexandrovich, this volume). Because Coscinodiscus marginatus is a relatively large diatom (Sancetta, 1982), samples prepared for radiolarian slides (randomly settled refractory material treated with hydrogen peroxide, hydrochloric acid, and washed through a $63 \mu \mathrm{m}$ sieve), readily recorded the occurrence of this diatom. The abundance of this diatom is so high in the $>63 \mu \mathrm{m}$ size fraction of the diatom oozes and clays, the material on the slides becomes several layers thick, which makes the slides look cloudy, and gives them a slightly reddish brown color. These properties were used to distinguish the top of the $C$. marginatus oozes without microscopic examination, which was then confirmed by microscopic examination.

Above the Coscinodiscus marginatus oozes the preservation and abundance of radiolarians decreases, and variations in the abundance of three states (complete frustules, fragmented frustules, and girdles) of Coscinodiscus marginatus were observed. Working upsection, a level was noted where Coscinodiscus marginatus remains were no longer found. Radiolarians in samples from above this level displayed large variations in assemblage composition, and variable preservation. More than $50 \%$ of the samples found above the last significant occurrence of $C$. marginatus were entirely barren of radiolarians. In samples with preserved radiolarians, siliceous sponge spicules were a major component at times.

A transition zone between well preserved late Pliocene and poorly preserved late Pliocene and Pleistocene radiolarian samples was noted in Holes 794A, 795A, and 797B. This zone was also evident in the diatom samples, and observations of both diatoms and radiolarians were used to precisely locate its boundaries (Table 4). Radiolarian samples from this interval were then rescanned, and semiquantitative estimates of the relative contribution of the major biogenic silica components (\%radiolarians, \%siliceous sponges, \%whole Coscinodiscus marginatus tests, \%fragmented $C$. marginatus tests, and $C$. marginatus girdles) were tabulated (Fig. 4). The presence of terrigenous material such as quartz was also noted in order to determine if samples were subjected to downslope transport.

\section{Chronology}

In order to discuss the progression of events observed in the diatom and radiolarian assemblages examined in this study, sample depths were assigned ages using age vs. depth data based on paleomagnetism and (largely diatom) biostratigraphy (Table 5). At the present time, this is the best age control available. Hole 794A has the most complete paleomagnetic record for the Quaternary and Pliocene. Because samples from Sites 794, 795, and 797 contain microfossil assemblages that display high variability in preservation, abundance, and species composition (both siliceous and calcareous), biostratigraphies are not easily tied to standard biozonations and well dated biostratigraphic sequences. In addition, biostratigraphic events (first and last occurrences) tied to the paleomagnetic time scale in the Pacific may not have occurred at the same time in the Japan Sea. Therefore, the age models for the Pliocene and Pleistocene of Sites 795 and 797 may be subject to revision. Until improved age models become available for Leg 127 sites, these age models (Table 5, Fig. 2) are used. 
Table 1. Abundance and preservation of Pliocene and Pleistocene diagnostic diatoms from Leg 127, Hole 794A, Japan Sea. Also shown is the abundance of sponge spicules throughout the core. Biostratigraphic zonation of the core is after Shipboard Scientific Party (1990b).

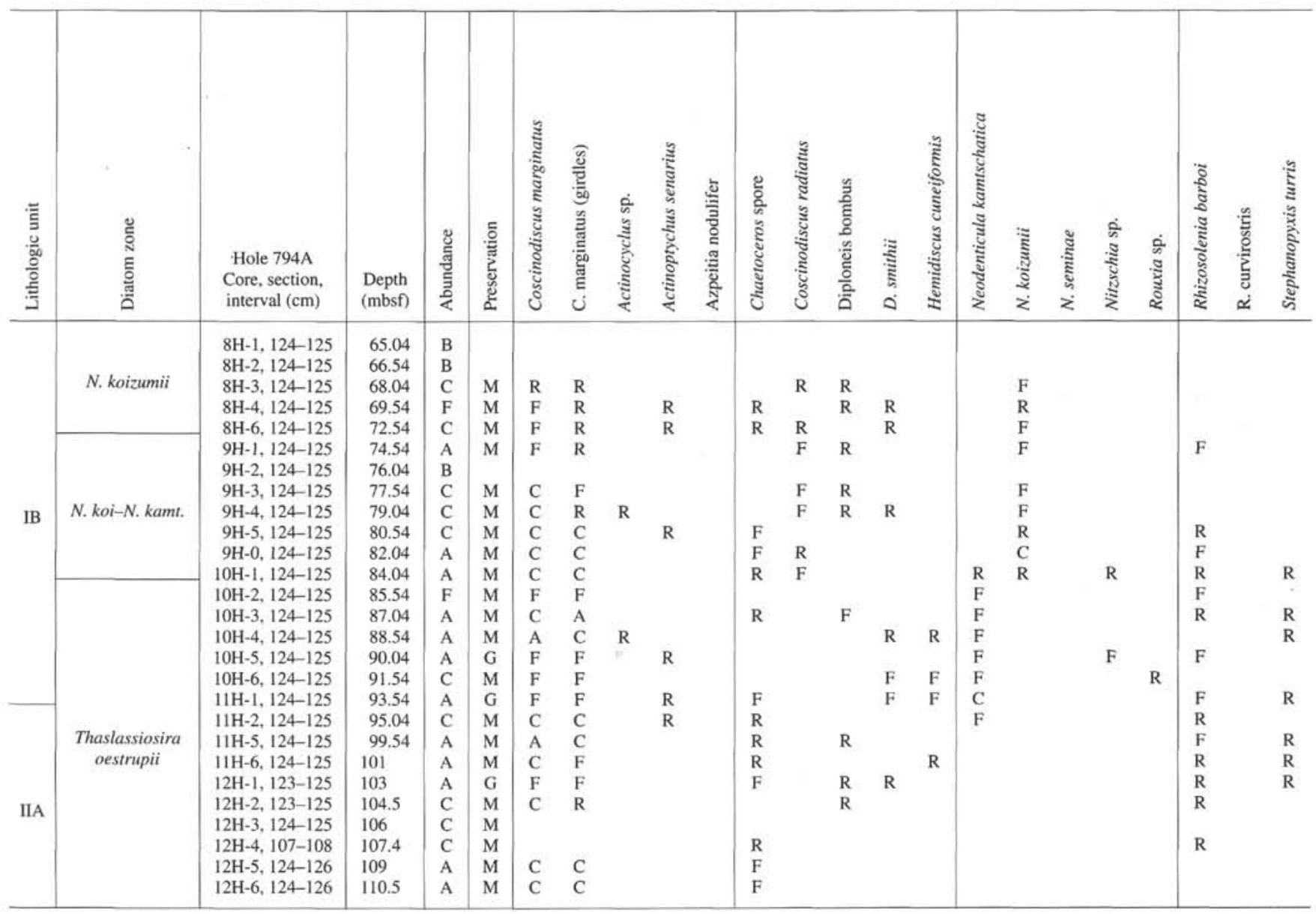

Abundances are abbreviated as follows: $\mathrm{A}=$ abundant, $\mathrm{C}=$ common, $\mathrm{F}=\mathrm{few}, \mathrm{R}=$ rare, and $\mathrm{B}=$ barren. For preservation, $\mathrm{G}=$ good, $\mathrm{M}=$ moderate, and $\mathrm{P}=$ poor.

\section{RESULTS}

Observations of the siliceous microfossil components in Japan Sea sediments suggest that the late Pliocene lithological change from clayey siliceous oozes to silty clays is accompanied by a transition from well preserved, relatively undissolved biogenic siliceous assemblages, to more poorly preserved, highly dissolved assemblages. The changes in diatoms and radiolarians that accompany this transition are discussed in the following section.

\section{Diatoms}

\section{Hole $794 A$}

In Hole 794A, the Pliocene diatoms in Samples 127-794A-12H-6, $124-126 \mathrm{~cm}$ (110.5 mbsf), through $-8 \mathrm{H}-3,124-125 \mathrm{~cm}$ (68.04 mbsf), are mostly common to abundant and show moderate preservation (Table 1, Pls. 1 and 2). The assemblages, which are part of the Thalassiosira oestrupii Zone to Neodenticula koizumii-N. kamtschatica Zone show few to abundant $C$. marginatus, $N$. kamtschatica, N. koizumii, Rhizosolenia barboi, Thalassionema nitzschioides, Thalassiothrix longissima, Thalassiosira oestrupii, and T. zabelinae (Table 1). Upper Pliocene Samples $127-794 \mathrm{~A}-8 \mathrm{H}-2,124-125 \mathrm{~cm}$, and $-8 \mathrm{H}-1,124-125 \mathrm{~cm}$, are barren of diatoms but have rare siliceous sponge spicules.

In the samples processed and examined for diatoms at Hole 794A $(<63 \mu \mathrm{m})$ the base of the ODTZ, as marked by the uppermost peak of C. marginatus abundances, occurs at 88.54 mbsf in Sample 127794A-10H-4, 124-125 cm (Tables 1 and 4, Fig. 3). The composition of the sediment at this depth (Unit IB) is silty clay to diatom silty clay (Shipboard Scientific Party, 1990b). Above this depth, C. marginatus gradually decreases and their frustules show greater fragmentation (Pls. 2 and 3). In addition, C. marginatus girdle bands show the greatest abundance just above the last peak of $C$. marginatus in Sample 127-794A-10H-3, 124-125 cm, at a depth of $87.04 \mathrm{mbsf}$ (Table 1 and Fig. 3). Other trends include increased occurrences of siliceous sponge spicules (few as compared to rare) above the base of the ODTZ (Table 1).

The top of the ODTZ in Hole 794A, as determined from slides examined for diatoms, is in Sample 127-794A-9H-3, 124-125 cm, at a depth of $77.54 \mathrm{mbsf}$, which is the last common occurrence of $C$. marginatus (Table 1, Fig. 3). Above the top of the transition zone the diversity of diatoms decreases to mostly dissolved frustules of Coscinodiscus radiatus, $N$. koizumii, and fragments of $T$. nitzschioides (Table 1), and in addition, the fraction of silt increases.

\section{Hole 795 A}

In Hole 795A, upper Pliocene and Pleistocene sediments also show decreasing abundances and preservation of diatoms above the maximum occurrence of $C$. marginatus in the diatom silty clays of lithologic Unit IB. Below this horizon, diatom assemblages within the upper Pliocene T. oestrupii to Neodenticula koizumii-N. kamtschatica Zone are common to abundant and overall show moderate to good states of preservation (Table 2). Diatoms of the upper Pliocene to Pleistocene $N$. koizumii and Actinocyclus oculatus Zone show more 
Table 1 (continued).

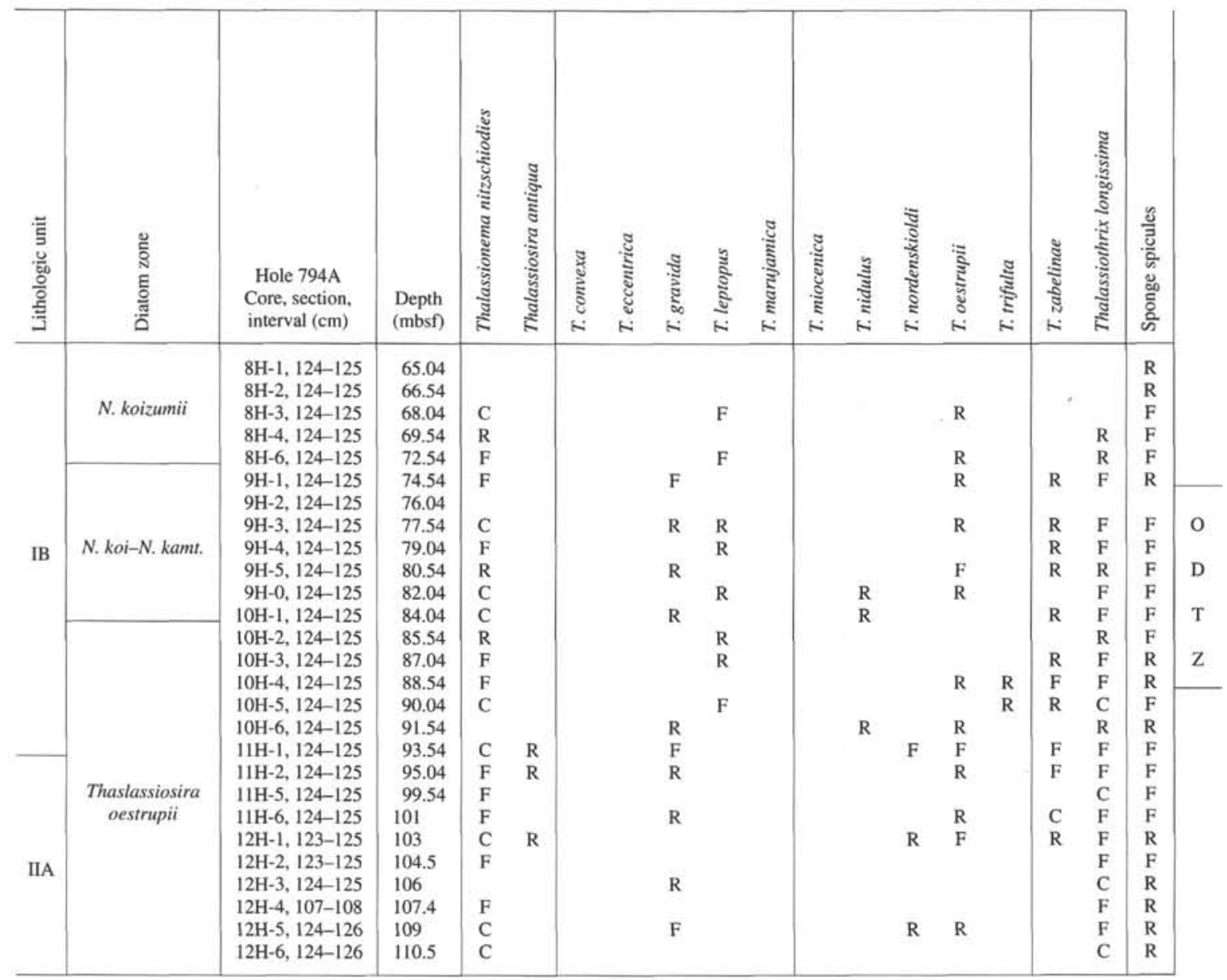

variable states of abundance and preservation. Similar to the assemblages in Hole 794A, Hole 795A assemblages are dominated by subtropical to subarctic planktonic diatom assemblages, with rare to few occurrences of benthic or nearshore diatoms such as Diploneis bombus, D. smithii, and Actinoptychus senarius (Table 2).

C. marginatus is much less common in Hole $795 \mathrm{~A}$ above Sample 127-795A-16H-3, 120-121 cm, at 146.50 mbsf (Tables 2 and 4, Fig. 3). Although there are common occurrences of $C$. marginatus above 146.50 mbsf in Samples 127-795A-15H-5, 120-121 cm, and $-15 \mathrm{H}-4,50-52 \mathrm{~cm}$, we generally recognize the base of the ODTZ between Samples 127$795 \mathrm{~A}-16 \mathrm{H}-4,74-79 \mathrm{~cm}$ (see radiolarian data), and $127-795 \mathrm{~A}-16 \mathrm{H}-3$, $120-121 \mathrm{~cm}$, at $147.54-146.50 \mathrm{mbsf}$ (Table 4), at the last consistent occurrence of common C. marginatus (Fig. 3). In addition to Sample 127-795A-16H-3, 120-121 cm, Samples 127-795A-16H-4, 115-116 $\mathrm{cm}$ (147.95 mbsf), and $-18 \mathrm{H}-1,120-121 \mathrm{~cm}(154.00 \mathrm{mbsf})$ also show common girdle bands of $C$. marginatus (Fig. 3). Above this horizon, silt-sized quartz grains are more evident.

In Sample 127-795A-13H-4, 120-121 cm, C. marginatus occurs with less frequency and the abundance of diatoms as a whole decreases (Table 2). Corresponding with this trend are higher abundances of sponge spicules (Zolnick et al., this volume; Pl. 2, Fig. 2).

\section{Hole $797 B$}

In Hole 797B, the base of the ODTZ as marked by the uppermost common occurrence of C. marginatus, occurs between Samples $127-$ 797B-13H-3, 22-24 cm (113.62 mbsf), and -13H-2, 118-120 cm (113.08 mbsf) (Table 4, Figs. 3-4, Pls. 1-3). Below this depth diatoms from the $N$. koizumii and $N$. koizumii-N. kamtschatica Zone are mostly com- mon to abundant but fluctuate with intervals containing fewer diatoms (Table 3). The assemblages below the base ODTZ are dominated by C. marginatus, C. radiatus, $N$. koizumii, N. kamtschatica, Thalassionema nitzschioides, and Thalassiosira zabelinae (Table 3).

The top of the ODTZ in Hole 797B is between 102.70 and $101.75 \mathrm{mbsf}$ (Table 4), in the slides examined for diatoms. The top of the zone was recognized in Sample 127-797B-12H-1, 22-24 cm where $C$. marginatus is less abundant (Table 3 and Fig. 3). As in Hole 794A, C. marginatus girdles are abundant within the transition zone at Hole 797B, probably as a result of extreme dissolution and increased downslope transport. Table 3 and Figure 4 (see discussion in the radiolarian section) also indicate the presence of common siliceous sponge spicules near the top of the ODTZ in Samples $127-797 \mathrm{~B}-12 \mathrm{H}-2,22-24 \mathrm{~cm}$ (102.62 mbsf), and $-12 \mathrm{H}-3,22-24 \mathrm{~cm}$ (104.12 mbsf).

\section{Radiolarians}

Semiquantitative estimates of the abundance of five different types of siliceous microfossils which are $>63 \mu \mathrm{m}$ in size (Fig. 4) show that the percent contribution of radiolarians (both whole and broken) is highly variable. In general, radiolarians increase between the base and the lower part of the opal dissolution transition zone. The upper portion of the ODTZ, particularly in Hole 795A, does not appear to have an increasing trend, and radiolarians are present in percentages $(\sim 40 \%)$ which are lower than those observed in samples from Holes $794 \mathrm{~A}$ and 797B. However, sponge spicules are present in higher abundances in samples from Hole 795 A and act to dilute the percentage of radiolarians in Hole 795A. The increased numbers of siliceous 
Table 2. Abundance and preservation of Pliocene and Pleistocene diagnostic diatoms from Leg 127, Hole 795A, Japan Sea. Also shown is the abundance of sponge spicules throughout the core. Biostratigraphic zonation of the core is after Shipboard Scientific Party (1990c).

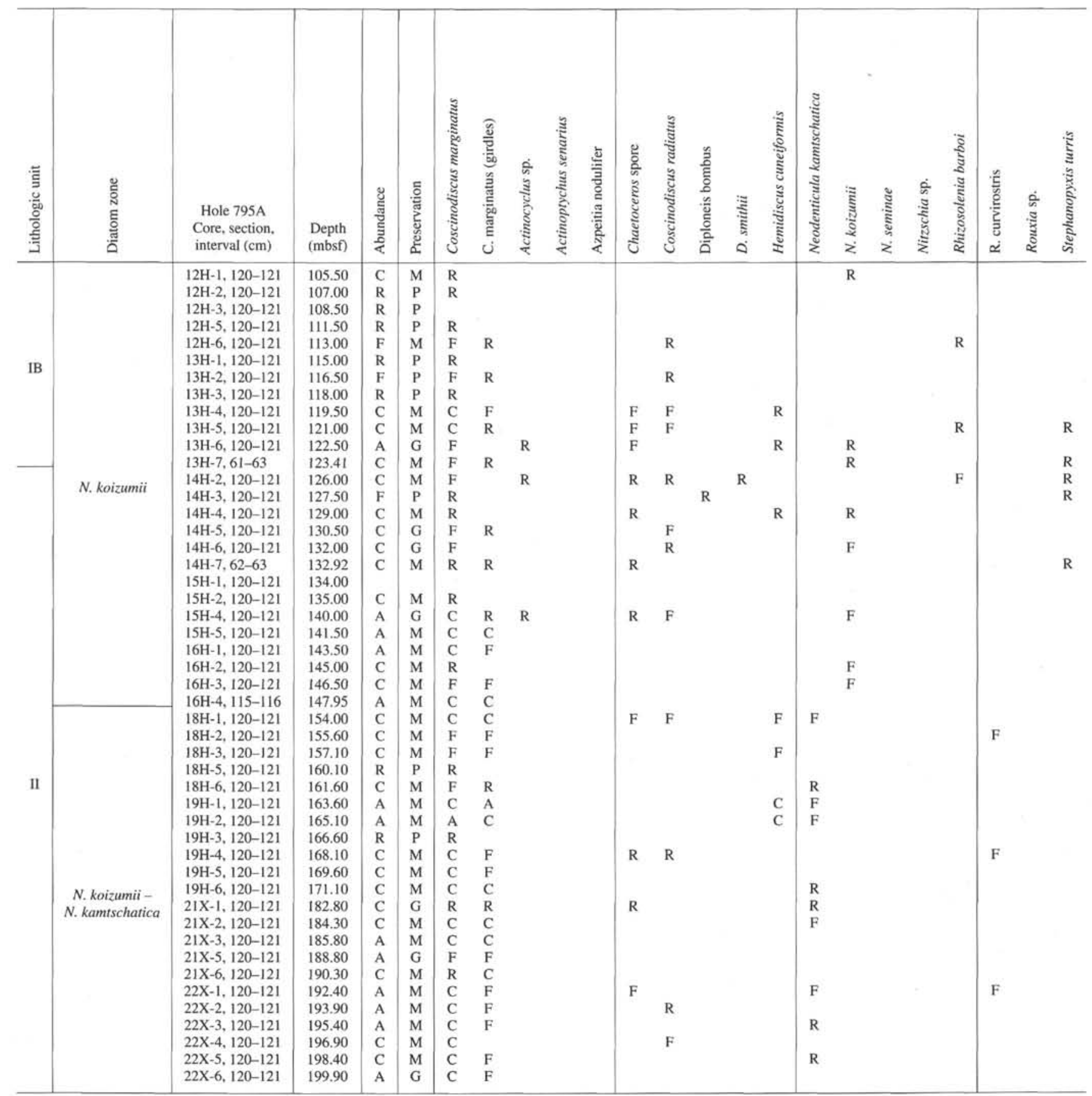

Abundances are abbreviated as follows: $\mathrm{A}=$ abundant, $\mathrm{C}=$ common, $\mathrm{F}=$ few, $\mathrm{R}=$ rare, and $\mathrm{B}=$ barren. For preservation, $\mathrm{G}=$ good, $\mathrm{M}=$ moderate, and $\mathrm{P}=$ poor.

sponge spicules in Hole 795A may be due to increased downslope transport at this site which would also explain the relatively high amount of microfossil reworking at this site (Shipboard Scientific Party, 1990c).

Percent whole Coscinodiscus marginatus generally decrease upsection within the opal dissolution transition zone, and is also found in higher abundances in Hole 795A. Percentages of broken C. marginatus also appear to decrease with increasing depth in the opal dissolution transition zone. However, there is a marked peak in the upper portion of this transition zone in Hole 797B. Trends are not obvious in the percent $C$. marginatus girdle records, but because the girdles appear to be heavily silicified, their presence seems to be an indicator of increased levels of dissolution.

Although these measurements (Fig. 4) represent only semiquantitative estimates of the relative contribution of the five main categories of siliceous microfossils, the general trends of decreasing percent C. marginatus, and fluctuating yet increasing percent radiolarians and siliceous sponge spicules upsection within the opal dissolution transition zone is observed. Since radiolarians and sponges are less susceptible to dissolution than are diatoms (Johnson, 1974), these data 
Table 2 (continued).

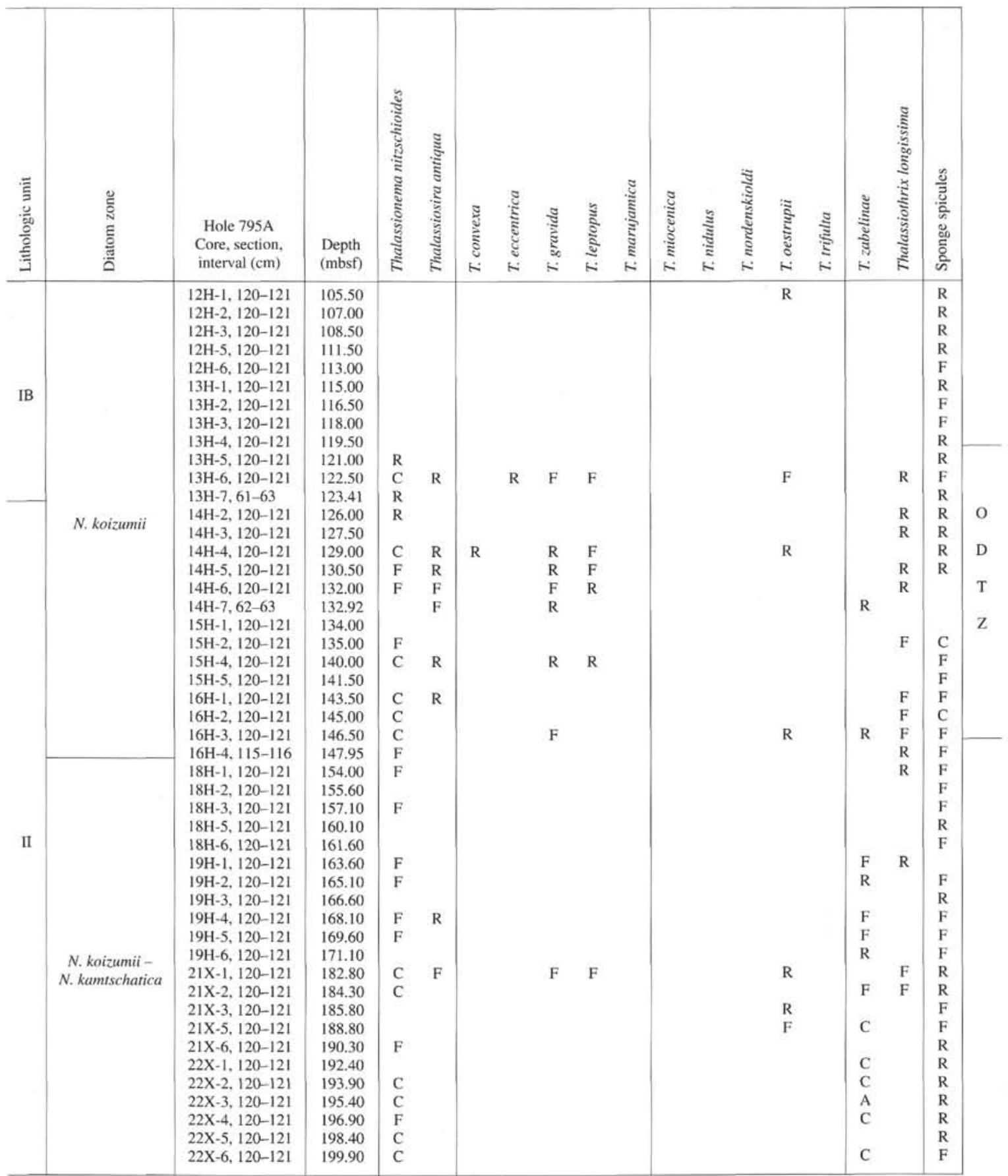

suggest that the siliceous assemblages over this interval were subjected to differing degrees of dissolution which, in general, increased with decreasing age. The diatomaceous intervals below the base of the opal dissolution transition zone contain high percentages of all three forms of Coscinodiscus marginatus, which serve as a diluting component in the slides making the relative contribution of radiolarians to the biosiliceous assemblages quite low (Pl. 1).

\section{ODTZ}

The opal dissolution transition zone is located by combining the information obtained from observations of slides prepared for diatom and radiolarian paleontological analyses (Figs. 3-4 and Pls. 1-3). The transition is very obvious in samples prepared for diatoms and radiolarians and occurs over the length of several cores. The ODTZ is thinnest $(9.6 \mathrm{~m})$ in Hole $794 \mathrm{~A}$, and thickest $(28 \mathrm{~m})$ in Hole $795 \mathrm{~A}$ (Table 4), and the time represented by these thicknesses is $\sim 400,000$ yr. The dissolution transition zones appear to be synchronous between Sites 795 and 797 (2.7-2.3 Ma, Table 4) while it is found in slightly older sediments in Hole 794A (2.9-2.6 Ma, Table 4). We believe that the opal dissolution transition zone is likely synchronous between all sites, and that the apparent diachroneity is caused by uncertain age control (probably in Holes 795A and 797B).

The opal dissolution transition zone roughly correlates to the transition from Unit I silty clays, to Unit II clayey diatom oozes at all three sites $(794,795$, and 797) as defined in Tamaki, Pisciotto, and 
Table 3. Abundance and preservation of Pliocene and Pleistocene diagnostic diatoms from ODP Leg 127, Hole 797B, Japan Sea. Also shown is the abundance of sponge spicules throughout the core. Biostratigraphic zonation of the core is after Shipboard Scientific Party (1990d).

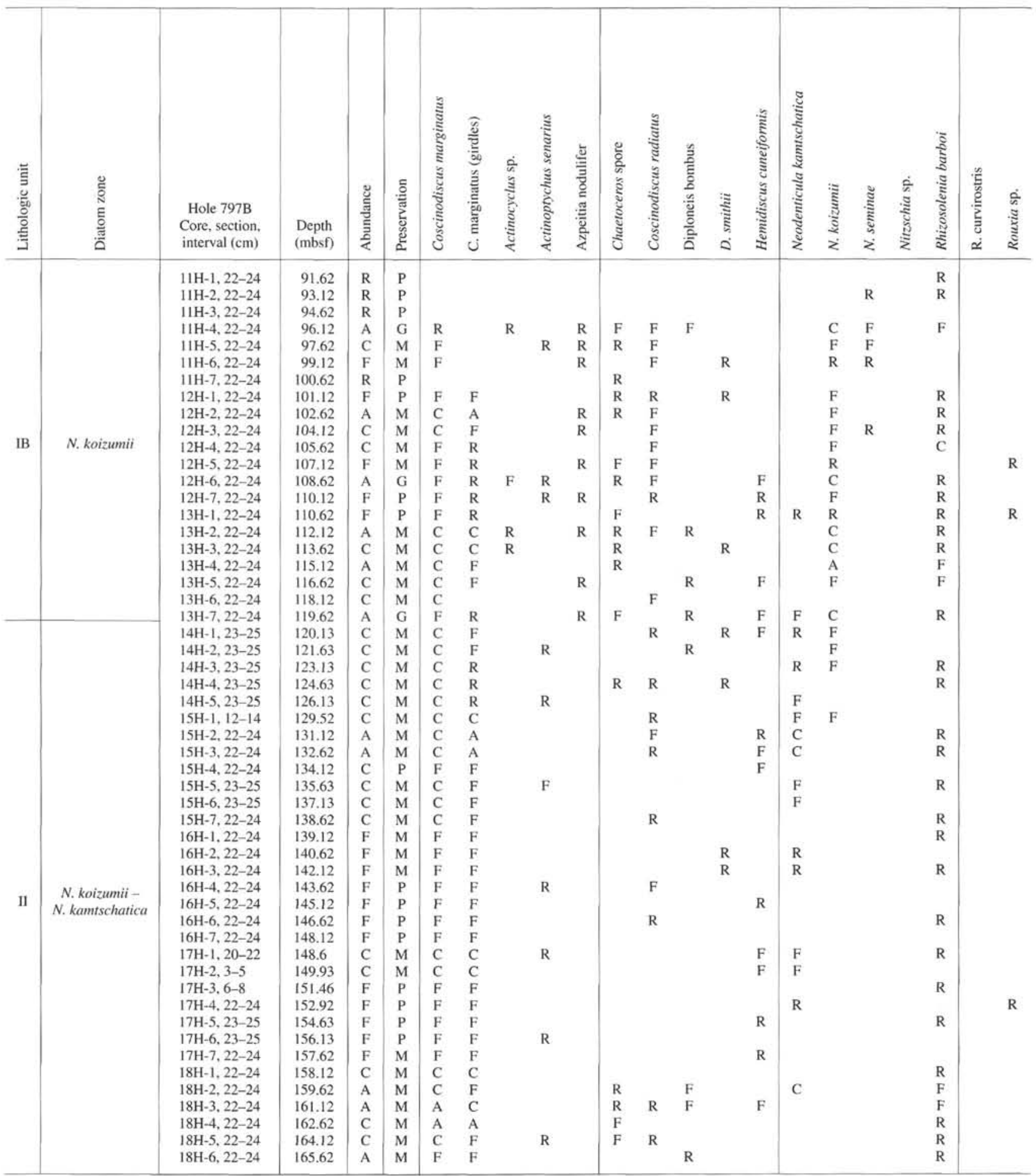

Abundances are abbreviated as follows: $\mathrm{A}=$ abundant, $\mathrm{C}=$ common, $\mathrm{F}=$ few, $\mathrm{R}=$ rare, and $\mathrm{B}=$ barren. For preservation, $\mathrm{G}=$ good, $\mathrm{M}=\mathrm{moderate}$, and $\mathrm{P}=$ poor. 
Table 3 (continued).

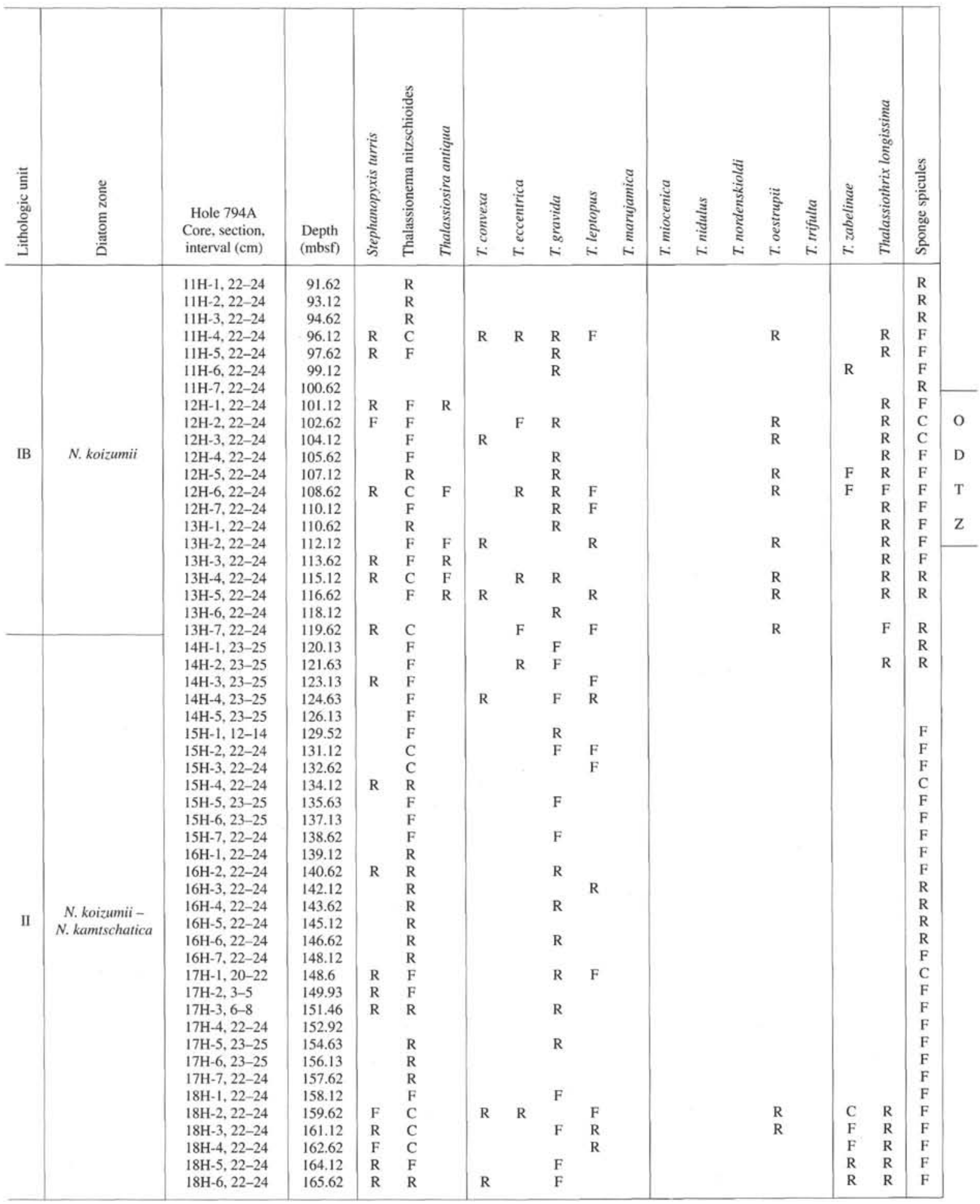

Allan, et al. (1990). The best correspondence of the opal dissolution transition zone with the lithologic units described during Leg 127 occurs in Hole 795A. The top of the transition zone in Hole 795A is found in Core 127-795A-13H-4 (Table 4). This level corresponds almost exactly to the top of Unit II which is distinguished by transitional indistinct color banding (Shipboard Scientific Party, 1990c). Although the opal dissolution transition zone appears to straddle the boundaries between lithological Units I and II in Holes 794A and
797B, the zone correlates well to smear slide records. The opal dissolution transition zone can be used to precisely define the transition between these two units.

\section{PALEOCEANOGRAPHIC INTERPRETATION}

There are three possible places where opal dissolution could have occurred. In the water column, on the seafloor at the sediment/water 
Table 4. Location by sample, depth, and age, of the top and bottom of the late Pliocene opal dissolution transition zone (ODTZ) in Sites 794, 795, and 797.

\begin{tabular}{|c|c|c|}
\hline $\begin{array}{c}\text { Top } \\
\text { ODTZ }\end{array}$ & $\begin{array}{l}\text { Bottom } \\
\text { ODTZ }\end{array}$ & $\begin{array}{l}\text { Thickness } \\
\text { ODTZ } \\
(m)\end{array}$ \\
\hline \multicolumn{3}{|l|}{ Hole 794A } \\
\hline $\begin{array}{c}-9 \mathrm{H}-3,59-61 \mathrm{~cm}, \text { to }-9 \mathrm{H}-3,124-125 \mathrm{~cm} \\
79.89-80.54 \mathrm{mbsf} \\
2.6 \mathrm{Ma}\end{array}$ & $\begin{array}{c}-10 \mathrm{H}-4,124-125 \mathrm{~cm}, \text { to }-10 \mathrm{H}-5,69-71 \mathrm{~cm} \\
88.54-89.49 \mathrm{mbsf} \\
2.9 \mathrm{Ma}\end{array}$ & $9.6 \mathrm{~m}$ \\
\hline \multicolumn{3}{|l|}{ Hole 795A } \\
\hline $\begin{array}{c}-13 \mathrm{H}-4,120-121 \mathrm{~cm}, \text { to }-13 \mathrm{H}-5,74-76 \mathrm{~cm} \\
119.50-120.54 \mathrm{mbsf} \\
2.3 \mathrm{Ma}\end{array}$ & $\begin{array}{c}-16 \mathrm{H}-3,120-121 \mathrm{~cm}, \text { to }-16 \mathrm{H}-4,74-76 \mathrm{~cm} \\
146.50-147.54 \mathrm{mbsf} \\
2.7 \mathrm{Ma}\end{array}$ & $28.04 \mathrm{~m}$ \\
\hline \multicolumn{3}{|l|}{ Hole 797B } \\
\hline $\begin{array}{c}-12 \mathrm{H}-1,22-24 \mathrm{~cm}, \text { to }-12 \mathrm{H}-1,117-119 \mathrm{~cm} \\
101.75-102.7 \mathrm{mbsf} \\
2.3 \mathrm{Ma}\end{array}$ & $\begin{array}{c}-13 \mathrm{H}-2,118-120 \mathrm{~cm}, \text { to }-13 \mathrm{H}-3,22-24 \mathrm{~cm} \\
113.08-113.62 \mathrm{mbsf} \\
2.6 \mathrm{Ma}\end{array}$ & $11.87 \mathrm{~m}$ \\
\hline
\end{tabular}

Ages were calculated using the age models of Table 5 and Figure 2, and rounded to the nearest $100,000 \mathrm{yr}$.

interface, or within the sediments. Post-depositional diagenetic processes can be ruled out as the cause of siliceous microfossil dissolution and Coscinodiscus marginatus concentration in the late Pliocene and Pleistocene sediments of Japan Sea Sites 794, 795, and 797. As the opal A/CT transition migrates upward, deeper sections would start dissolving earlier, and if $C$. marginatus was concentrated by diagenetic dissolution, the percentages of $C$. marginatus would be higher deeper in the sections, and this is not the case.

Dissolution at the sediment/water interface cannot be ruled out entirely, because there is some evidence which suggests that dissolution on the seafloor was important during the deposition of the Pleistocene dark and light layers (Alexandrovich, this volume). However, since sediment accumulation (burial) rates of the dissolved (upper Pliocene and Pleistocene) assemblages are not significantly lower than the burial rates of the Miocene and lower Pliocene diatomaceous oozes, the substantial increases in dissolution of the assemblages probably did not occur at the sediment/water interface.

The increased dissolution could have occurred in the water column prior to deposition as a result of depletion of available dissolved silica and competition for silica by plankton. Because Coscinodiscus marginatus is a dissolution-resistant species (Burckle, Sturz, and Emanuele, this volume), and is no longer present in any significant abundance ( $<5 \%$ of siliceous material) in the upper Pliocene and Pleistocene samples, we must assume that productivity declined during the opal dissolution transition zone. This seems to imply that during intervals of diatomaceous ooze deposition, circulation of the Japan Sea was quite different than it is today.

The age of the opal dissolution transition zone corresponds to a time of global cooling and build up of Northern Hemisphere glaciers (Barron and Baldauf, 1989; Raymo et al., 1990). Although the timing of these two events might suggest that the depositional changes were caused by cooling, it seems unlikely that cooling could be the sole cause of the changes since diatoms can be very productive in cold waters. However, because low numbers of radiolarians/gm (and generally poorer preservation) found in the sediments of piston core RC12-379 (Morley et al., 1986) are correlated to glacial stages, cooling may be a partial cause of the decreased preservation, or apparent reduced productivity, of the Pleistocene Japan Sea.

Dissolution and decreased productivity of siliceous microplankton implies that the waters of the Japan Sea became depleted with respect to dissolved silica. Matoba (1984) showed the depth of the sill at the Tsugaru Strait decreased rather rapidly between the late Pliocene and Pleistocene. If the dissolved silica content of Pacific deep waters of the Pliocene were similar to today's, a reduction of the influx of Pacific water into the Japan Sea at the Tsugaru Strait could have caused concentrations of dissolved silica in the Japan Sea to decrease. In turn, decreased silica concentrations would serve to lower productivity and increase dissolution of siliceous microorganisms.

\section{SUMMARY}

Abundance and preservation of siliceous microfossils is strongly controlled by the environmental constraints at the time of deposition. One of the most critical controls is the concentration of silica in the bottom water that is, in turn, related to circulation of deep water and upwelling patterns. Two key driving forces in the movement of deep water are (1) cooling of water, necessary to drive thermohaline circulation; and (2) bathymetry, which determines the flow path of bottom water.

The record of the subtropical to subarctic diatom Coscinodiscus marginatus suggests it is an especially sensitive indicator of not only diatom productivity, but its physical robustness is useful in determining preservation of siliceous microfossil assemblages. Its peak abundance in upper Pliocene sediments of the Japan Sea is synchronous in Holes $795 \mathrm{~A}$ and $797 \mathrm{~B}$ and is estimated to be $2.4 \mathrm{Ma}$. This age agrees well with $C$. marginatus abundances in the North Pacific and its relationship to the migration of the subarctic front and oceanwide water mass restructuring events (Sancetta and Silvestri, 1986). This interpretation is further supported by diatom data from DSDP Sites 578-580 in the northwest Pacific by Koizumi (1986). The high abundance of $C$. marginatus marks the base of what we have termed the opal dissolution transition zone (ODTZ) and it appears to be a few $100,000 \mathrm{yr}$ older in Hole 794A (2.9 Ma). We suggest that this diachronous distribution may be an artifact of dating methods and needs to be further investigated.

The peak abundance of $C$. marginatus between 2.9 and $2.5 \mathrm{Ma}$ is followed by some distinctive changes in the opaline fossil assemblages. Generally speaking, in the $10-30 \mathrm{~m}$ overlying very abundant C. marginatus, diatom frustules become increasingly fragmented, resulting in numerous disarticulated girdle bands in the sediments. Radiolarians within this interval are generally more poorly preserved, and siliceous sponge spicules appear to show a slight increase in numbers. The base of the ODTZ roughly correlates to the cessation of diatom oozes and the increase of silty and clay-dominated sediments in the Japan Sea. This pattern of increasing dissolution after the peak of $C$. marginatus reaches a threshold between 2.5 and $2.0 \mathrm{Ma}$ where $C$. marginatus ceases to be a significant component of the siliceous microfossil assemblages. 
Table 5. Age control points for Leg 127 Sites 794, 795 , and 797 .

\begin{tabular}{|c|c|c|c|}
\hline $\begin{array}{l}\text { Depth } \\
\text { (mbsf) }\end{array}$ & $\begin{array}{l}\text { Age } \\
(\mathrm{Ma})\end{array}$ & $\begin{array}{c}\text { Control } \\
\text { point }\end{array}$ & $\begin{array}{c}\text { Rate } \\
(\mathrm{m} / \mathrm{m} . \mathrm{y} .)\end{array}$ \\
\hline \multicolumn{4}{|l|}{ Site 794} \\
\hline \multicolumn{4}{|l|}{0.000 .00} \\
\hline 24.60 & 0.73 & $\mathrm{p}$ & 33.699 \\
\hline 31.10 & 0.90 & $\mathrm{p}$ & 38.325 \\
\hline 34.10 & 0.98 & $\mathrm{p}$ & 37.500 \\
\hline 54.60 & 1.66 & $\mathrm{p}$ & 30.147 \\
\hline 58.80 & 1.88 & $\mathrm{p}$ & 19.091 \\
\hline 75.40 & 2.47 & p & 28.136 \\
\hline 89.80 & 2.92 & p & 32.000 \\
\hline 92.30 & 2.99 & $\mathrm{p}$ & 35.714 \\
\hline 95.50 & 3.08 & p & 35.556 \\
\hline 98.80 & 3.18 & $\mathrm{p}$ & 33.000 \\
\hline 108.20 & 3.40 & $\mathrm{p}$ & 42.727 \\
\hline 125.10 & 3.88 & $\mathrm{p}$ & 35.208 \\
\hline 126.70 & 3.97 & $\mathrm{p}$ & 17.778 \\
\hline 133.80 & 4.10 & $\mathrm{p}$ & 54.615 \\
\hline 135.90 & 4.24 & $\mathrm{p}$ & 15.000 \\
\hline 139.90 & 4.40 & $\mathrm{p}$ & 25.000 \\
\hline 140.40 & 4.47 & p & 7.143 \\
\hline 143.80 & 4.57 & $\mathrm{p}$ & 34.000 \\
\hline 148.50 & 4.77 & $\mathrm{p}$ & 23.500 \\
\hline 216.90 & 6.40 & d & 41.963 \\
\hline 255.70 & 7.20 & d & 48.500 \\
\hline 293.50 & 7.90 & d & 54.000 \\
\hline 530.50 & 14.40 & c & 36.462 \\
\hline 540.00 & 16.00 & f & 5.937 \\
\hline \multicolumn{4}{|l|}{ Site 795} \\
\hline \multicolumn{4}{|l|}{0.000 .00} \\
\hline 35.00 & 0.73 & $\mathrm{p}$ & 47.945 \\
\hline 46.00 & 0.90 & $\mathrm{p}$ & 64.706 \\
\hline 48.60 & 0.98 & $\mathrm{p}$ & 32.500 \\
\hline 87.00 & 1.66 & $\mathrm{p}$ & 56.471 \\
\hline 97.20 & 1.88 & $\mathrm{p}$ & 46.364 \\
\hline 134.00 & 2.50 & d & 58.871 \\
\hline 200.90 & 3.50 & d & 66.900 \\
\hline 327.20 & 5.30 & d & 70.167 \\
\hline 394.40 & 6.40 & d & 61.091 \\
\hline 481.10 & 9.00 & d & 33.346 \\
\hline 560.50 & 10.70 & d & 46.706 \\
\hline 605.70 & 11.60 & c & 50.222 \\
\hline 635.30 & 13.30 & d & 17.412 \\
\hline
\end{tabular}

Site 797

$\begin{array}{rrrr}0.000 .00 & & & \\ 38.30 & 0.73 & \mathrm{p} & 52.466 \\ 78.60 & 1.66 & \mathrm{p} & 43.333 \\ 81.90 & 1.80 & \mathrm{~d} & 23.571 \\ 84.60 & 1.88 & \mathrm{p} & 33.750 \\ 126.00 & 2.92 & \mathrm{p} & 39.808 \\ 133.80 & 2.99 & \mathrm{p} & 111.429 \\ 143.60 & 3.08 & \mathrm{p} & 108.889 \\ 150.80 & 3.18 & \mathrm{p} & 72.000 \\ 167.80 & 3.40 & \mathrm{p} & 77.273 \\ 243.40 & 5.30 & \mathrm{~d} & 39.789 \\ 350.00 & 7.20 & \mathrm{~d} & 56.105 \\ 369.60 & 11.60 & \mathrm{c} & 4.455 \\ 439.10 & 14.40 & \mathrm{c} & 24.821 \\ 493.50 & 17.10 & \mathrm{c} & 20.148\end{array}$

Paleomagnetic data are from Hamano et al. (this volume), and biostratigraphic data are from Shipboard Scientific Party (1990b. 1990c, and 1990e) with the exception of the LO of Neodenticula kamtschatica (2.5 Ma control point) in Site 795 which is from Koizumi (this volume). $\mathrm{P}$ refers to paleomagnetic control point, and $\mathrm{d}, \mathrm{c}$, and $\mathrm{f}$. to diatom datum, coccolith, and foraminifer level control point, respectively.
Age (Ma)

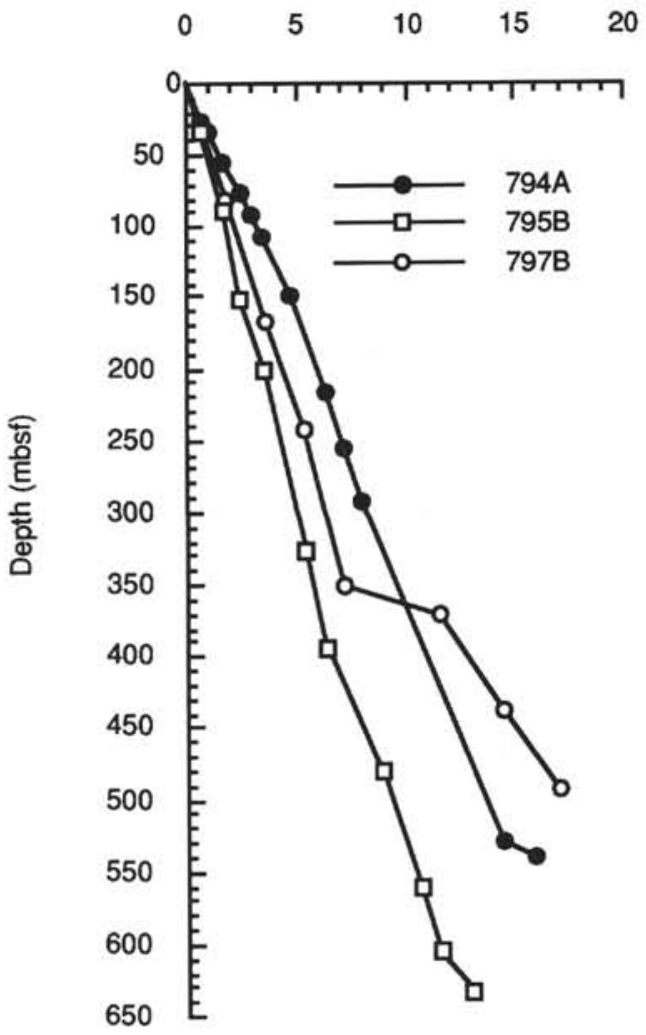

Figure 2. Age vs. depth of Sites 794, 795, and 797.

The complex tectonic setting of the Japan Sea, coupled with Neogene high latitude glaciations, resulted in a Pliocene through Pleistocene depositional setting that was particularly sensitive to water mass fluctuations. The decreasing sill depth of the Tsugaru Strait during the late Pliocene and Pleistocene, in response to lowering of sea level brought on by Northern Hemisphere glaciation, likely resulted in a reduction of the influx of Pacific water into the Japan Sea and, therefore, a reduction in dissolved silica contents in the Japan Sea. Thus, the dissolved siliceous microfossil assemblages observed at Sites 794, 795, and 797 record global temperature and circulation changes that were intensified in the marginal basin setting of the Japan Sea.

\section{FLORAL LIST}

Actinocyclus oculatus Jousé

Actinocyclus sp.

Actinoptychus senarius (Ehrenberg) Ehrenberg

Azpeitia nodulifer (Schmidt) Fryxell and Sims

Chaetoceros Ehrenberg

Coscinodiscus marginatus Ehrenberg

Coscinodiscus radiatus Ehrenberg

Diploneis bombus Ehrenberg

Diploneis smithii (Brebisson) Cleve

Hemidiscus cuneiformis Wallich

Neodenticula kamtschatica (Zabelina) Akiba and Yanagisawa

Neodenticula koizumii Akiba and Yanagisawa

Neodenticula seminae (Simonsen and Kanaya) Akiba and Yanagisawa 
Site 794

$\%$ Coscinodiscus marginatus

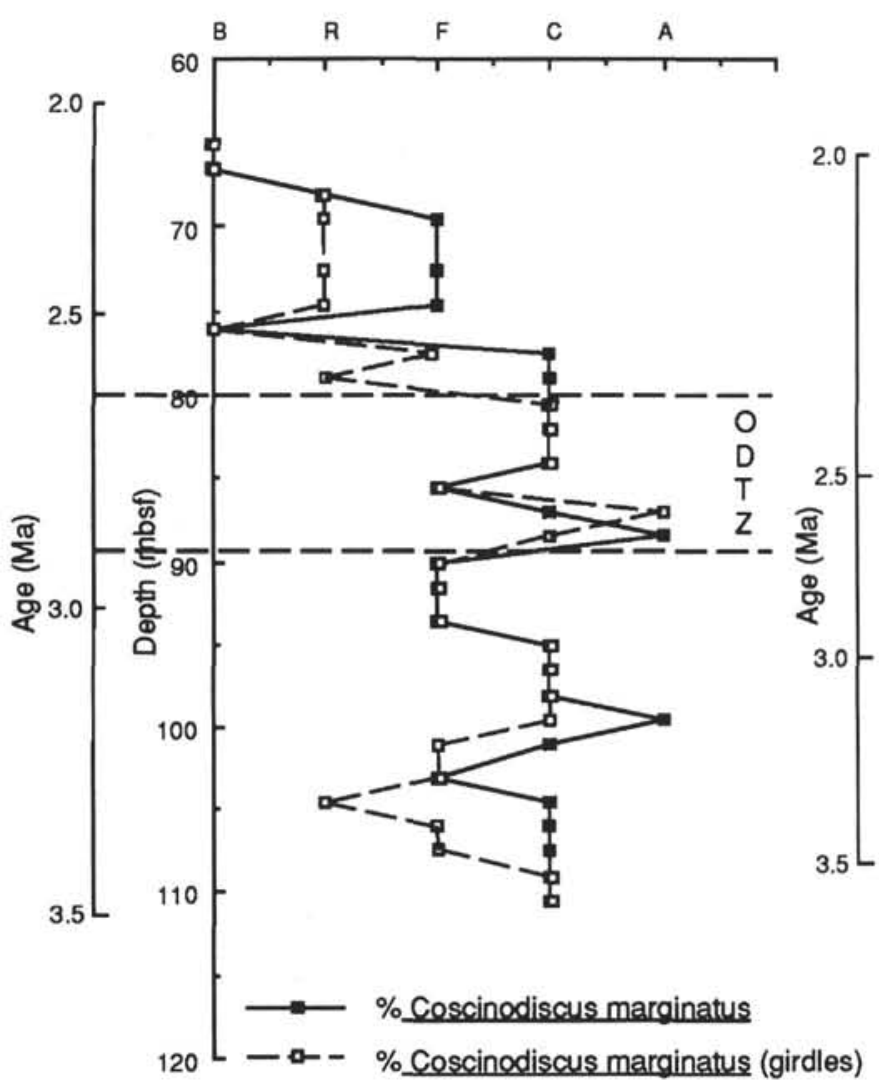

Site 795

$\%$ Coscinodiscus marginatus

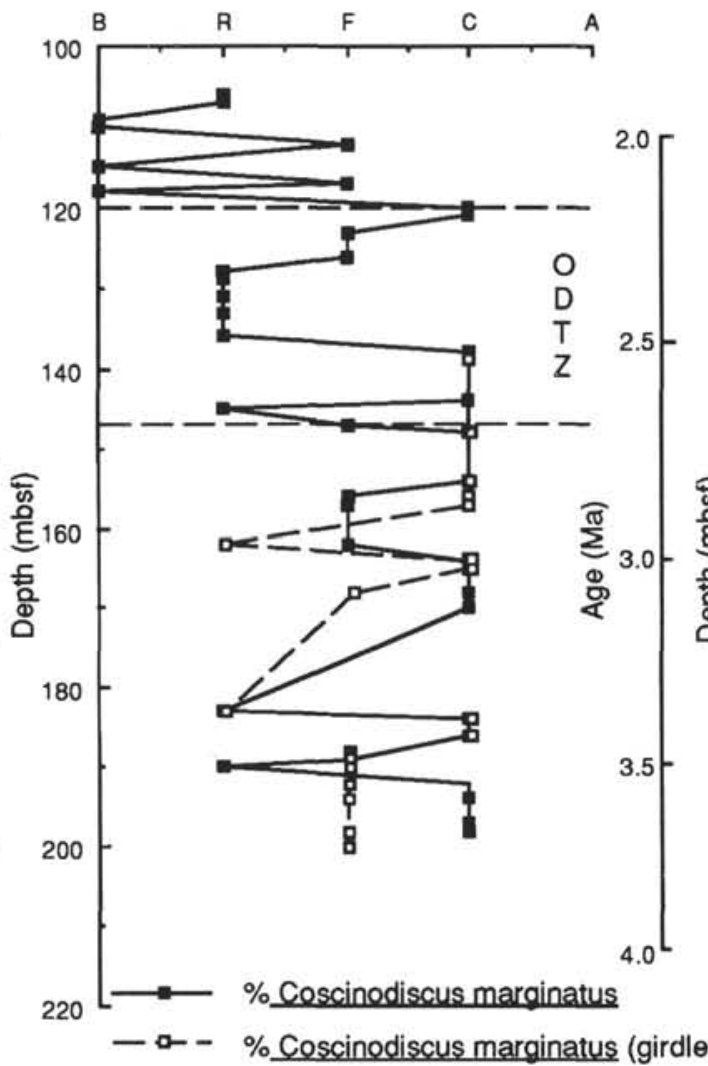

Site 797

$\%$ Coscinodiscus marginatus

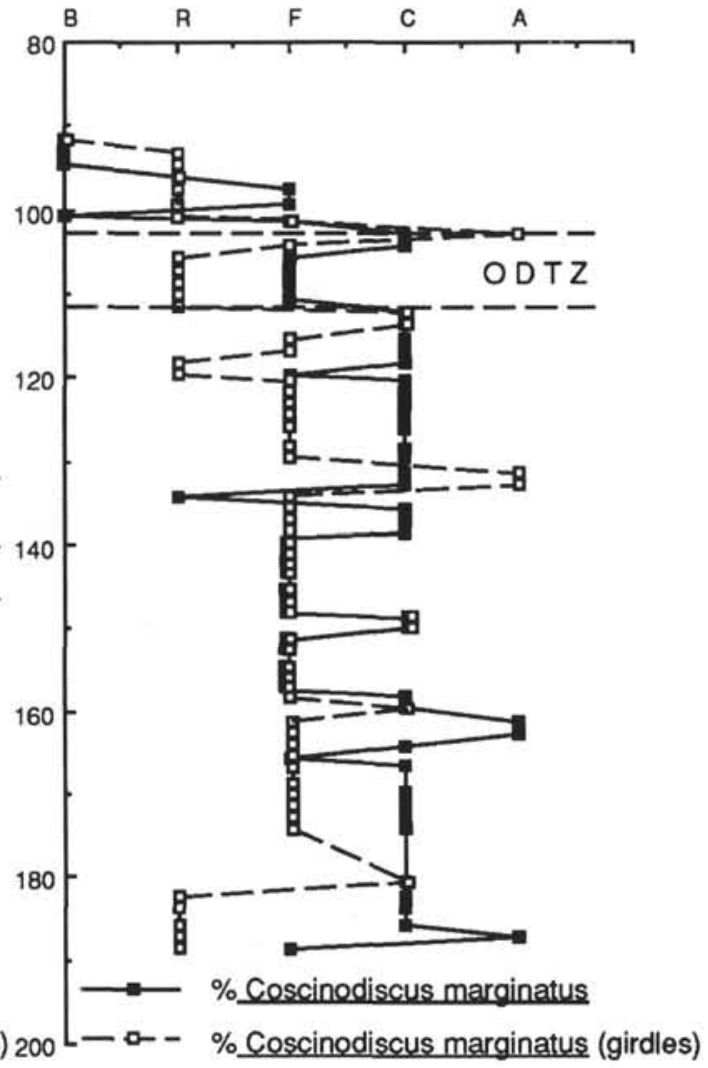

Figure 3. Variation in the relative abundance of Coscinodiscus marginatus and C. marginatus girdles in Pliocene-Pleistocene sediments from Hole 794A, 795A, and 797B. Note the peak in C. marginatus girdles at a depth slightly above the last major occurrence of $C$. marginatus frustules, in Holes 794A and 797B. Abundancea are abbreviated as follows: $A=$ abundant, $\mathrm{C}=$ common, $\mathrm{F}=$ few, $\mathrm{R}=$ rare, $\mathrm{B}=\mathrm{barren}$. 

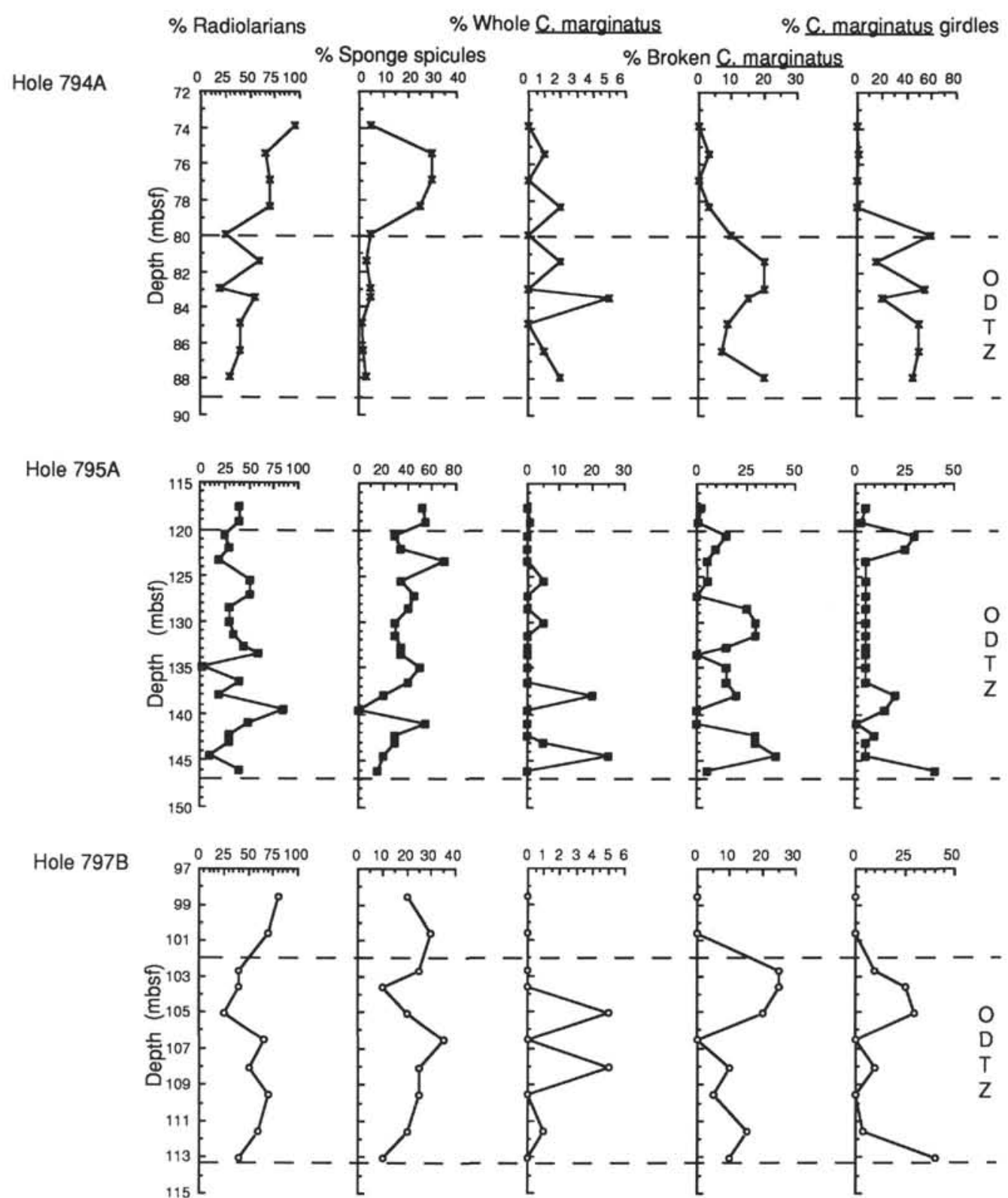

Figure 4. Semiquantitative estimates of the breakdown of biosiliceous material on slides prepared for radiolarians in the Japan Sea opal dissolution transition zone. Radiolarian fragments were included in the \%radiolarians category. Note differences in percent scales.

Nitzschia sp.

Rhizosolenia barboi (Brun) Tempere and Peragallo

Rhizosolenia curvirostris Jousé

Stephanopyxis turris (Grev. and Arn.) Ralfs

Thalassionema nitzschioides (Grunow) Peragallo

Thalassiosira antiqua (Grunow) Cleve-Euler

Thalassiosira convexa Muchina

Thalassiosira eccentrica (Ehrenberg) Cleve

Thalassiosira gravida Cleve

Thalassiosira leptopus (Grunow) Hasle and Fryxell

Thalassiosira marujamica Sheshukova-Poretzkaya

Thalassiosira nidulus (Tempère and Brun) Jousé

Thalassiosira nordenskioldi Cleve

Thalassiosira oestrupii (Ostenfeld) Proshkina-Labrenko

Thalassiosira trifulta Fryxell

Thalassiosira zabelinae Jousé

Thalassiothrix longissima Cleve and Grunow

\section{ACKNOWLEDGMENTS}

Funding for this research was provided by JOI U.S. Science Support Program. This research would not have been possible without the laboratory assistance of Ann Melamed, Leslie Hewitt, and Laura Pound, all of San Francisco State University, and of Elaine Stock. Manuscript reviews by John Barron, Naja Mikkelsen, and Joe Morley are greatly appreciated.

\section{REFERENCES}

Barron, J. A., and Baldauf, J. G., 1989. Tertiary cooling steps and paleoproductivity as reflected by diatoms and biosiliceous sediments. In Berger, W. H., Smetacek, V. S., and Wefer, G. (Eds.), Productivity of the Ocean: Present and Past: New York (Wiley), 341-354.

Holdsworth, B. K., and Harker, B. M., 1975. Possible indicators of degree of Radiolaria dissolution in calcareous sediments of the Ontong-Java Plateau. 
In Andrews, J. E., Packham, G., et al., Init. Repts. DSDP, 30: Washington (U.S. Govt. Printing Office), 489-497.

lijima, A., and Tada, R., 1990. Evolution of Tertiary sedimentary basins of Japan in reference to opening of the Japan Sea. J. Fac. Sci., Univ. Tokyo, $22: 121-171$.

Ingle, J. C., Jr., 1975. Pleistocene and Pliocene Foraminifera from the Sea of Japan, Leg 31, Deep Sea Drilling Project. In Karig, D. E., Ingle, J. C., Jr., et al., Init. Repts. DSDP, 31: Washington (U.S. Govt. Printing Office), 693-701.

Kobayashi, K., 1985. Sea of Japan and Okinawa Trough. In Nairn, A.E.M., Stehli, F. G., and Uyeda, S. (Eds.), The Ocean Basins and Margins (Vol. 7A): The Pacific Ocean: New York (Plenum), 419-457.

Koizumi, I., 1986. Pliocene and Pleistocene diatom datum levels related with paleoceanography in the northwest Pacific. Mar. Micropaleontol., 10:309-325.

1989. Holocene pulses of diatom growths in the warm Tsushima current in the Japan Sea. Diatom Res., 4:55-68.

Leg 127 and Leg 128 Shipboard Scientific Parties, 1990. Evolution of the Japan Sea. Nature, 346:18-20.

Leinen, M., Cwienk, D., Heath, G. R., Biscaye, P. E., Kolla, V., Thiede, J., and Daupin, J. P., 1986. Distribution of biogenic silica and quartz in recent deep-sea sediments. Geology, 14:199-203.

Matoba, Y., 1984. Paleoenvironment of the Sea of Japan. In Oertli, H. J. (Ed.), Benthos '83: Proc. 2nd Int. Conf. Benthic Foraminifera, 409-414.

Morley, J. J., Heusser, L. E., and Sarro, T., 1986. Latest Pleistocene and Holocene palaeoenvironment of Japan and its marginal sea. Palaeogeogr., Palaeoclimatol., Palaeoecol., 53:349-358.

Oba, T., Kato, M., Kitazato, H., Koizumi, I., Omura, A., Sakai, T., and Takayama, T., 1991. Paleoenvironmental changes in the Japan Sea during the last 85,000 years. Paleoceanography, 6:499-518.

Raymo, M. E., Ruddiman, W. F., Shackleton, N. J., and Oppo, D. W., 1990. Evolution of global ice volume and Atlantic-Pacific $\delta^{13} \mathrm{C}$ gradients over the last 2.5 m.y. Earth Planet. Sci. Lett., 97:353-368.

Riedel, W. R., and Foreman, H. P., 1961. Type specimens of North American Paleozoic radiolaria $J$. Paleontol., 35:628-632.
Sancetta, C., 1982. Distribution of diatom species in surface sediments of the Bering and Okhotsk seas. Micropaleontology, 28:221-257.

Sancetta, C., and Silvestri, S., 1986. Pliocene-Pleistocene evolution of the North Pacific ocean-atmosphere system, interpreted from fossil diatoms. Paleoceanography, 1:163-180.

Schrader, H. J., 1973. Cenozoic diatoms from the Northeast Pacific, Leg 18. In Kulm, L. D., von Huene, R., et al., Init. Repts. DSDP, 18: Washington (U.S. Govt. Printing Office), 673-797.

Shipboard Scientific Party, 1990a. Explanatory notes. In Tamaki, K., Pisciotto, K., Allan, J., et al., Proc. ODP, Init. Repts., 127: College Station, TX (Ocean Drilling Program), 35-59.

1990b. Site 794. In Tamaki, K., Pisciotto, K., Allan, J., et al., Proc. ODP, Init. Repts., 127: College Station, TX (Ocean Drilling Program), $71-167$.

, 1990c. Site 795. In Tamaki, K., Pisciotto, K., Allan, J., et al., Proc. ODP, Init. Repts., 127: College Station, TX (Ocean Drilling Program), $169-245$.

1990d. Site 796. In Tamaki, K., Pisciotto, K., Allan, J., et al., Proc. ODP, Init. Repts., 127: College Station, TX (Ocean Drilling Program), 247-322.

1990e. Site 797. In Tamaki, K., Pisciotto, K., Allan, J., et al., Proc. ODP, Init. Repts., 127: College Station, TX (Ocean Drilling Program), 323-421.

Tamaki, K., 1988. Geological structure of the Japan Sea and its tectonic implications. Chishitsu Chosasho Geppo, 39:269-365.

Tamaki, K., Pisciotto, K., Allan, J., et al., 1990. Proc. ODP, Init. Repts., 127: College Station, TX (Ocean Drilling Program).

Date of initial receipt: 22 April 1991

Date of acceptance: 26 February 1992

Ms 127/128B-140 


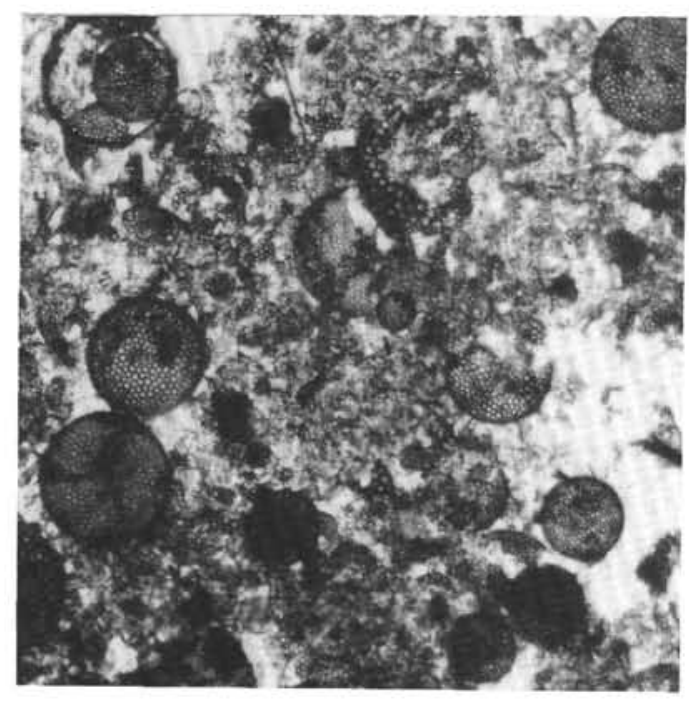

1

$\overline{80 \mu \mathrm{m}}$
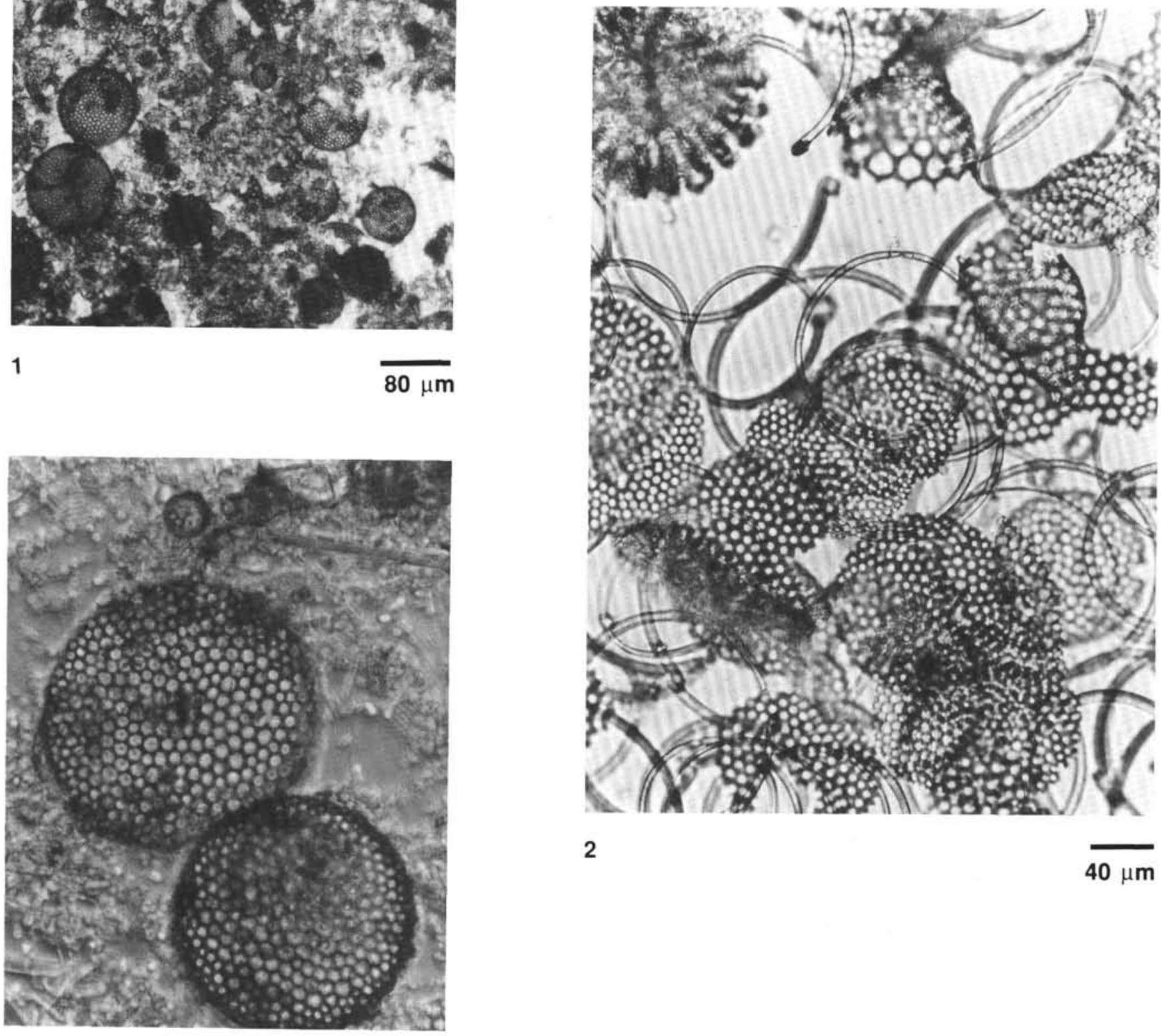

3

$20 \mu \mathrm{m}$

Photographs presented in the following plates were taken using a $35 \mathrm{~mm}$ camera mounted on a beam splitter on a Wild M20 microscope and a Zeiss Axioskop. Scale are indicated on the plates. EF refers to the England Finder location (Riedel and Foreman, 1961) of the specimen on the sample slide. Samples are kept at the Department of Geosciences, San Francisco State University, and the Department of Geology, Florida Atlantic University.

Plate 1. Photomicrographs from samples found below the opal dissolution transition zone. Coscinodiscus marginatus valves largely intact, showing little dissolution. Both whole girdles and valves largely intact. 1. Sample $127-797 \mathrm{~B}-13 \mathrm{H}-4,22-24 \mathrm{~cm}$. 2. Sample 127-794A-11H-1, 60-62 cm, EF P19/3-4. 3. Sample 127-797B-13H-4, 22-24 cm. 


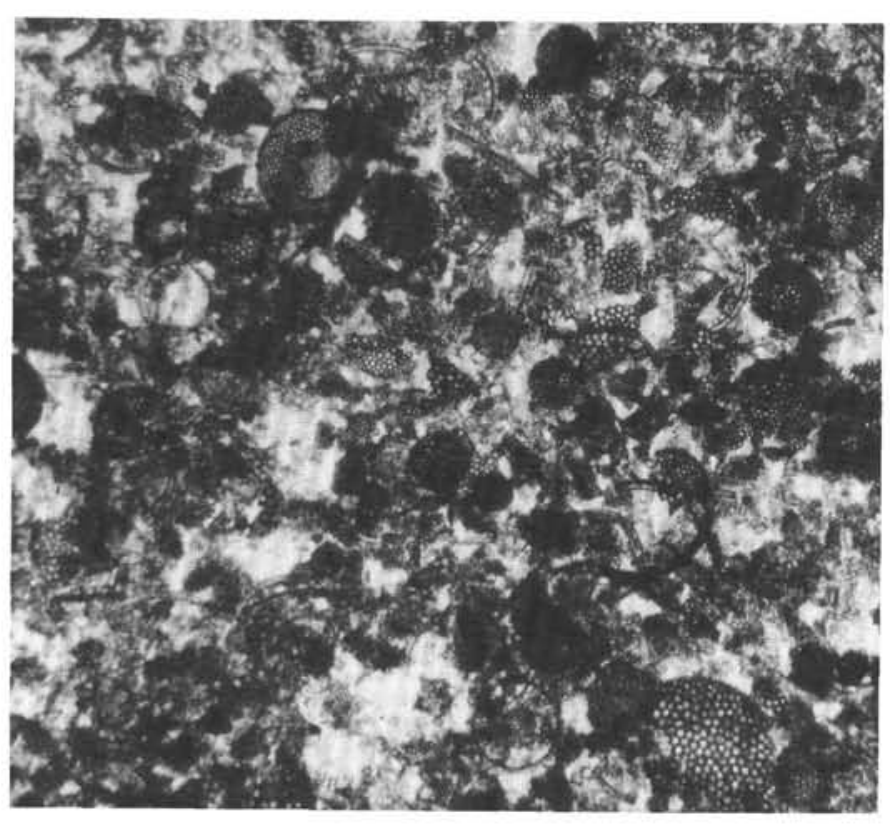

1

$\overline{80 \mu \mathrm{m}}$

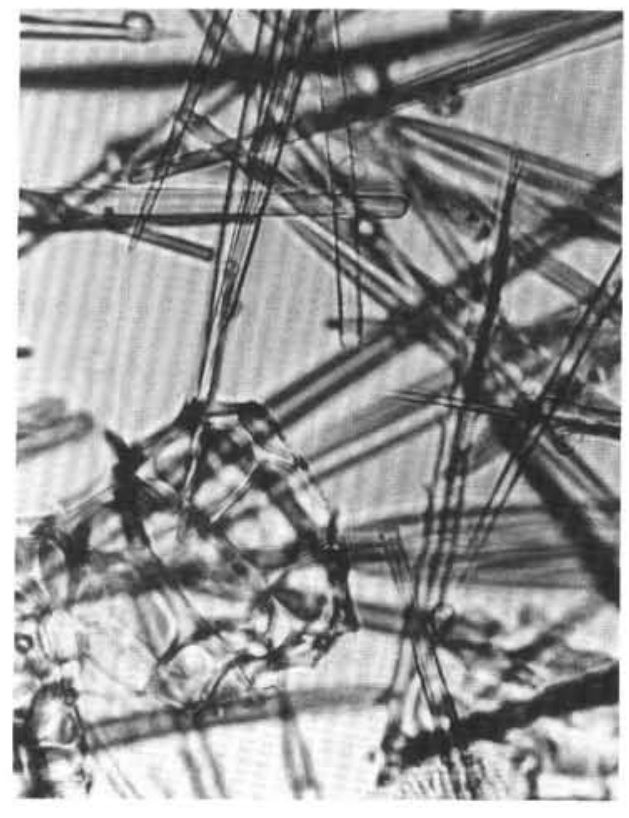

2

$\overline{40 \mu \mathrm{m}}$

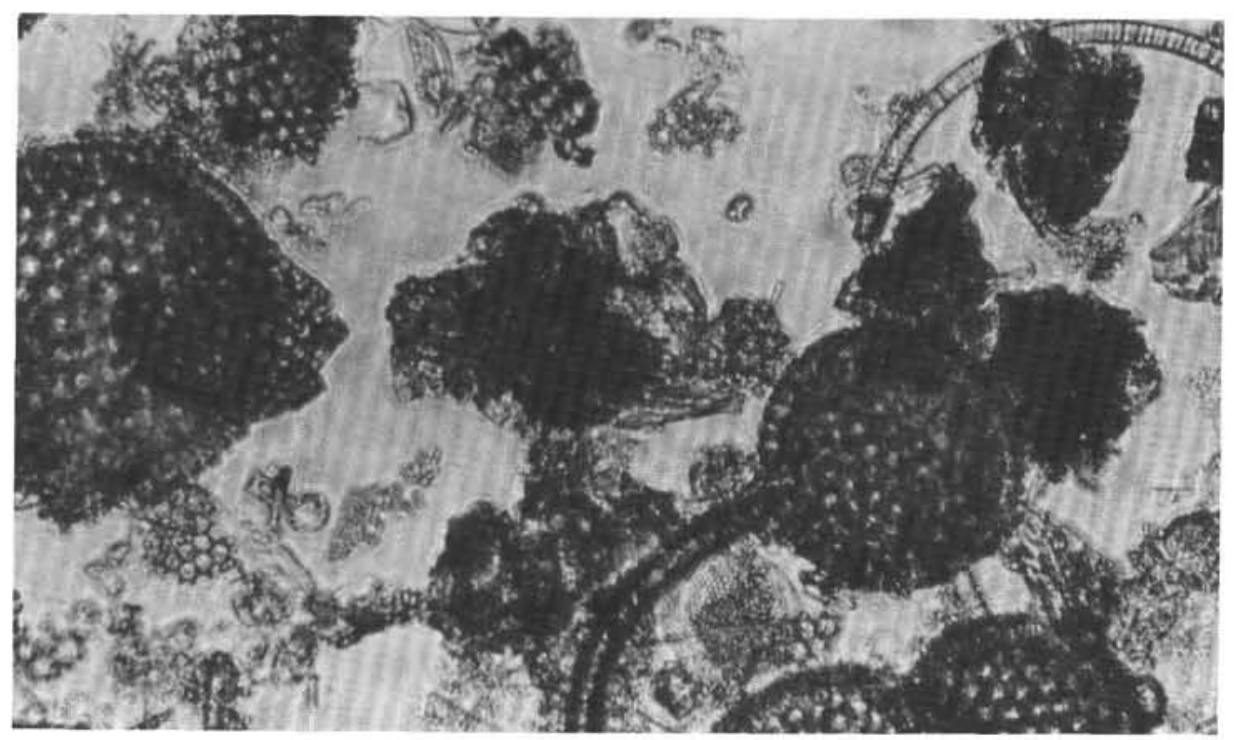

3

$20 \mu \mathrm{m}$

Plate 2. Photomicrographs from samples found within the opal dissolution transition zone. Diatom valves show signs of dissolution and fragmentation ( 1 and 3 ) and samples prepared for radiolarians contain high abundances of siliceous sponge spicules (2). 1. Sample 127-797B-12H-2, 22-24 cm. 2. Sample 127-795A$13 \mathrm{H}-7,51-53 \mathrm{~cm}, \mathrm{EF}$ H10/4. 3. Sample 127-794A-9H-6, 124-125 cm. 


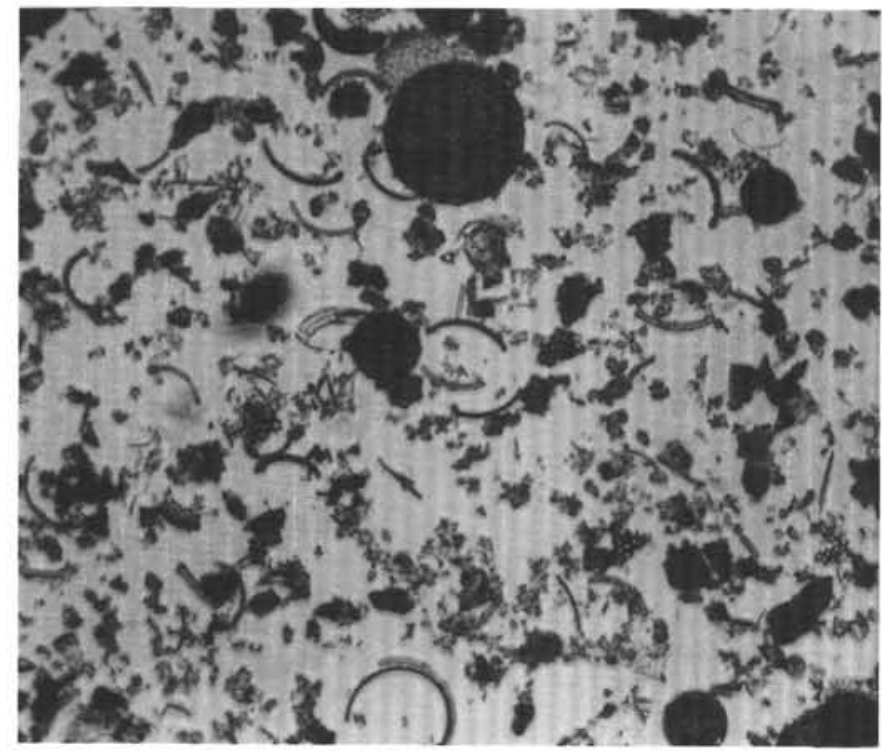

1
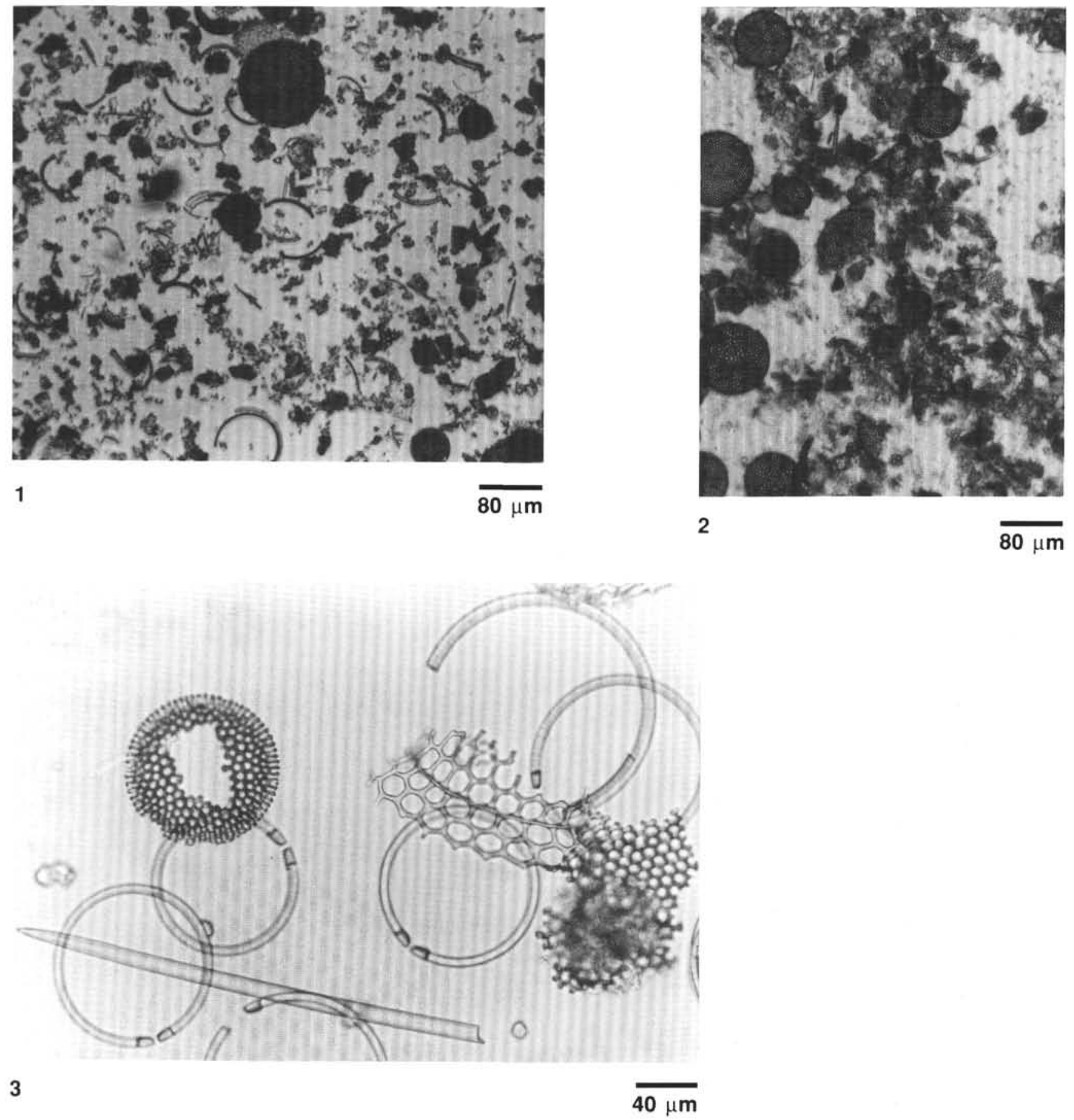

Plate 3. Photomicrographs from samples found within the opal dissolution transition zone. Diatom valves are dissolved and fragmented (1,2, and 3), and broken diatom girdles are abundant (1 and 2). 1. Sample 127-794A-10H-3, 124-125 cm. 2. Sample 127-797B-13H-2, 22-24 cm. 3. Sample 127-794A-9H-6, $59-61 \mathrm{~cm}, \mathrm{EF} \mathrm{K} 12 / 3$. 